\title{
Catalyst, Membrane, Free Electrolyte Challenges, and Pathways to Resolutions in High Temperature Polymer Electrolyte Membrane Fuel Cells
}

\author{
Timothy Myles ${ }^{1}$, Leonard Bonville ${ }^{1}$ and Radenka Maric ${ }^{1,2,3, *}$ \\ 1 Center for Clean Energy Engineering, University of Connecticut, Storrs, CT 06269, USA; \\ tdm05003@engr.uconn.edu (T.M.); bonville@engr.uconn.edu (L.B.) \\ 2 Department of Material Science and Engineering, University of Connecticut, Storrs, CT 06269, USA \\ 3 Department of Chemical \& Biomolecular Engineering, University of Connecticut, Storrs, CT 06269, USA \\ * Correspondence: maric@engr.uconn.edu; Tel.: +1-860-486-2756
}

Academic Editor: Martin van Sint Annaland

Received: 1 December 2016; Accepted: 29 December 2016; Published: 6 January 2017

\begin{abstract}
High temperature polymer electrolyte membrane fuel cells (HT-PEMFCs) are being studied due to a number of benefits offered versus their low temperature counterparts, including co-generation of heat and power, high tolerance to fuel impurities, and simpler system design. Approximately $90 \%$ of the literature on HT-PEM is related to the electrolyte and, for the most part, these electrolytes all use free phosphoric acid, or similar free acid, as the ion conductor. A major issue with using phosphoric acid based electrolytes is the free acid in the electrodes. The presence of the acid on the catalyst sites leads to poor oxygen activity, low solubility/diffusion, and can block electrochemical sites through phosphate adsorption. This review will focus on these issues and the steps that have been taken to alleviate these obstacles. The intention is this review may then serve as a tool for finding a solution path in the community.
\end{abstract}

Keywords: free electrolyte; phosphoric acid; HT-PEMFC

\section{Introduction}

\subsection{Motivation for HT-PEMFC}

Proton exchange membrane fuel cells (PEMFC) are well-established, having demonstrated excellent performance and respectable durability. However, several serious obstacles to broad commercialization remain. The state-of-the-art for this technology is based on a Nafion ${ }^{\mathrm{TM}}$ membrane and platinum $(\mathrm{Pt})$ on carbon catalyst, assembled with carbon/carbon Teflon gas diffusion layers, and carbon bipolar plates. While there have been many applications of this technology, most of them showing superior performance while running on ultrapure hydrogen/air at a temperature between $30^{\circ} \mathrm{C}$ and $80^{\circ} \mathrm{C}$, the high cost of production along with issues of freezing at low temperatures and long start up times has prevented them from being accepted for cost critical applications such as transportation [1]. The key cost sensitive elements of this technology are identified as the high cost of the Nafion ${ }^{\mathrm{TM}}$ membrane, platinum catalysts, and carbon machining for bipolar plates. These costs added to the lack of pure hydrogen infrastructure and the high cost of hydrogen itself, have presented an obstacle to the introduction of commercial fuel cells for several decades.

In an effort to alleviate some of the operational issues with the state of the art (SOA) low temperature PEMFCs, a new classification was developed, high temperature PEMFCs (HT-PEMFCs). As the name implies, these PEMFCs operate at higher temperatures than their SOA low temperature counterparts. The general distinction in operating temperature between SOA low temperature 
PEMFCs (LT-PEMFCs) and HT-PEMFCs is $60-80^{\circ} \mathrm{C}$ for LT-PEMFCs vs. $100-250{ }^{\circ} \mathrm{C}$ for HT-PEMFCs. The HT-PEMFCs can be broken into two ranges for further analysis.

\subsection{Low Range HT-PEMFC: $100-150{ }^{\circ} \mathrm{C}$}

Significant operational improvements can be achieved with a moderate increase in PEM operating temperatures including increased electrode reaction kinetics, increased carbon monoxide tolerance, improved heat management, improved water management, and at least theoretically, the potential for using non-platinum catalyst [2-4]. Addressing each one of these individually, increasing operational temperature of PEM fuel cells improves the reaction kinetics of both the anode and the cathode, however since the over-potential of the cathode (ORR) accounts for the majority of the voltage losses for PEM, the cathode has been and remains the major focus of electrode research $[3,5]$. While the associated increase in power density with increased temperature is a significant advantage, conductivity limitations with both Nafion ${ }^{\mathrm{TM}}$ and with sulfonated poly ether ether ketone (SPEEK), sulfonated poly ether ketone (SPEK) and other membrane alternatives have resulted in the need to dope the membrane with phosphoric acid or similar acid. The consequence of adding these acids is a significant decrease in the oxygen reduction reaction (ORR) due to their slow kinetics, low oxygen solubility (high mass transport losses), and phosphate absorption induced losses of the electrode surface area. These are fundamental and will continue to result in net performance losses until improve membranes or improved electrolyte dopants are identified. This topic is deferred until later in the paper.

Carbon monoxide (CO) tolerance is increased from $10-20 \mathrm{ppm}$ at $80^{\circ} \mathrm{C}$ to $1000 \mathrm{ppm}$ at $120{ }^{\circ} \mathrm{C}$. [6]. This increase in $\mathrm{CO}$ tolerance provides the basis for significant system simplification and cost reduction. This improved CO tolerance allows the selective oxidizer to be eliminated, as well as the high temperature shift converter. It also allows significant simplification of the low temperature shift converter design and controls, as well as the option for using low-cost shift converter catalysts.

The benefits in the area of heat management are dependent only on the power plant system efficiency and operating temperature. Operating the stack at $80{ }^{\circ} \mathrm{C}$ with an efficiency of $40 \%$ to $50 \%$ requires a heat rejection system (radiator) approximately twice as large as those that are currently used in automobiles. Increasing the operating temperature above $120^{\circ} \mathrm{C}$ will eliminate that penalty and allow the use of heat rejection systems that are currently available with the commensurate cost, volume, and weight savings. [7].

Raising the system temperature from $80^{\circ} \mathrm{C}$ to greater than $130^{\circ} \mathrm{C}$ has a twofold advantage for water management. If cells are run at less than $100{ }^{\circ} \mathrm{C}$, at atmospheric pressure, water exist in both the liquid and vapor phases. Liquid water that collects and remains in the cathode can cause very high reactant mass transport losses. If this water is not properly managed, it can result in flooded electrodes [8]. In addition to these electrode losses, when reactant gas humidity is high, water can condense and locally block flow channels in the flow field plates. This water condensation and flow field blockage can be catastrophic, especially for stack designs that use multi-pass flow fields. Operating above $100{ }^{\circ} \mathrm{C}$ ensures only vapor phase water is present. Additionally, the use of phosphoric acid doped systems allows for the design of systems without the need for any humidification. While the increase in system operating temperature from $80^{\circ}$ to $150^{\circ}$ has the potential to allow the use of non-platinum catalyst, the current catalyst development status suggests that higher temperatures are required.

\subsection{High Range HT-PEMFC: $150-250^{\circ} \mathrm{C}$}

High temperature PEM fuel cells have the same five basic operating advantages that were identified for low temperature PEM, however the magnitude of the operating advantages is increased in this case. While operating at these temperatures has proven to be too high for Nafion ${ }^{\mathrm{TM}}$, alternative membranes such as PBI and pyridine (commercial names Celtec and Advent) doped with phosphoric acid have demonstrated respectable performance and durability [9-16].

Addressing the improvements associated with increasing the operating temperature from $150{ }^{\circ} \mathrm{C}$ to $200{ }^{\circ} \mathrm{C}$, first, it is noted that open circuit voltage, cathode kinetics, and the Tafel slope is further 
improved when compared to the temperature increase from $80{ }^{\circ} \mathrm{C}$ to $150{ }^{\circ} \mathrm{C}$ [5]. Considering the performance penalties associated with using phosphoric acid rather than Nafion ${ }^{\mathrm{TM}}$, the improvements associated with increasing temperature to $180-200{ }^{\circ} \mathrm{C}$ result in performance levels that are considered acceptable, at least for niche market applications. Further improvements associated with improved oxygen solubility and phosphate contamination will be discussed in Sections 5 and 6 respectively.

The increase of temperature to $200{ }^{\circ} \mathrm{C}$ increases CO tolerances to $30,000 \mathrm{ppm}$ [6]. This level of $\mathrm{CO}$ tolerance allows for significant reduction of the cost of the hydrogen generation and purifying subsystem. With this level of tolerance to $\mathrm{CO}$, it is estimated that $3 \% \mathrm{CO}$ in hydrogen can be tolerated for current densities up to $0.8 \mathrm{~A} / \mathrm{cm}^{2}$ at $200{ }^{\circ} \mathrm{C}$ as compared to only $0.1 \% \mathrm{CO}$ that can be tolerated for current densities less than $0.3 \mathrm{~A} / \mathrm{cm}^{2}$ at $125^{\circ} \mathrm{C}$.

In the area of thermal management, further reductions in heat exchanger sizes as well as the pump size and parasite power are available with a temperature increased to $180-200^{\circ} \mathrm{C}$, when compared to the operating temperature of $130-150{ }^{\circ} \mathrm{C}$. In addition, increasing the operating temperature to $180{ }^{\circ} \mathrm{C}$ or higher provide sufficient thermal driving force and thermal energy to support thermal recovery systems that can be used to provide heat, hot water, low-grade steam, or even drive air-conditioning equipment. This additional energy recovery can be sufficient to increase the total power plant efficiency, electrical plus thermal efficiency, from $40 \%$ to $80 \%$. It is recognized that these efficiency improvements can only be captured at installations where that type of energy is useful.

In addition to the improvements in water management that are achieved when temperatures are increased to $200{ }^{\circ} \mathrm{C}$, the higher temperature opens the opportunity for lower platinum loading electrodes, and with further development, even non-platinum catalysts.

\subsection{Challenges in Implementations}

Despite the advantages of HT-PEMFCs versus LT-PEMFCs, there are major roadblocks which prevent them from being a viable alternative. Finding a polymer electrolyte material that exhibits good conductivity and stability at these temperatures is a major challenge. While increasing system operating temperature, even moderately, can produce significant performance and cost advantages, there are also disadvantages. Increasing temperature increases corrosion rates for the platinum catalyst, the carbon catalyst support, the bipolar plates, and the membrane itself. Increases in corrosion rates for the platinum catalyst results in faster and more severe losses of the electrochemical surface area (ECSA) and therefore performance. The corrosion of the carbon catalyst support results in the loss of electronic contact of the platinum catalyst with the carbon support which also results in loss of ECSA. The increase in corrosion rates for the bipolar plates result in an increase in contact resistance and eventually the loss of reactant containment, either reactant to reactant or reactant to external. In either case these corrosion induced stack failures can result in significant safety issues including stack failure. Additionally, the widespread use of phosphoric acid doping leads to the inevitable presence of free electrolyte in the fuel cell electrodes. In fact, this free electrolyte becomes crucial to cell performance as it acts as the ionic phase conductor in the electrode. This leads to issues that have been plaguing the phosphoric acid fuel cell (PAFC) community for decades, including poor oxygen activity in phosphoric acid, low oxygen permeability in phosphoric acid, phosphate adsorption onto the catalyst surface, and electrolyte movement within the cell [17-20]. SOA phosphoric acid based systems use 3-5 mg PGM $/ \mathrm{cm}^{2}$ (platinum group metals) amounting to $\$ 750-1000 / \mathrm{KW}$ in cost [21]. In light of these issues, this short review will focus on the current state of technology relating to these free electrolyte issues. Specifically, this review will summarize the progress which has been made in the community in tackling each of these issues with the intention of being used as a tool for future improvements in this area of HT-PEMFCs.

\section{High Temperature Polymer Electrolyte Membranes}

Before proceeding with a review of challenges and resolution paths relating to the free electrolyte issues in HT-PEMFCs it is necessary to briefly set the stage in terms of electrolyte developments 
which led to the current state of the art. This section is not meant as a complete review of electrolyte materials for HT-PEMFC. For a complete review, the reader is directed to several key reviews of polymer membranes for HT-PEMFC applications which have been written over the past 10 years, including $\mathrm{Li}$ [22], Bose [23], Asensio [24], and Herring [25] to name a few. As far as polymer electrolytes are concerned, currently Nafion ${ }^{\mathrm{TM}}$ is the baseline that is used as a reference material for PEM fuel cell performance. It is normally operated at $60{ }^{\circ} \mathrm{C}-80^{\circ} \mathrm{C}$ and when fully saturated has performance that meets, or at least approaches target requirements for stationary applications. However, it is expensive, has low tolerance for impurities, especially carbon monoxide (CO) and requires complex systems and controls to keep it within the optimum operating conditions. Nafion ${ }^{\mathrm{TM}}$ is a solid membrane that is made of perfluorocarbon-sulfonic acid ionomer. It uses water to solvate the protons associated with the sulfonic acid functional groups giving it its proton conductivity and the proton conductivity is very sensitive to water content. When fully saturated, the conductivity of Nafion ${ }^{\mathrm{TM}}$ is 0.04 to $0.1 \mathrm{~S} \cdot \mathrm{cm}^{-1}$ depending on fabrication procedures and operating conditions, and decreases by several orders of magnitude as humidity (water content) is reduced $[2,26-30]$.

In an effort to improve performance, researchers initially attempted to run Nafion ${ }^{\mathrm{TM}}$ membranes in PEM cells at higher temperatures. These attempts were limited by two barriers. First, in order to keep the Nafion ${ }^{\mathrm{TM}}$ membrane fully saturated as cell operating temperatures reached $100^{\circ} \mathrm{C}$, system cost and complexity became sufficient to prohibit further increases in temperature. Unfortunately, operating at $100^{\circ} \mathrm{C}$ is not sufficient to significantly improve tolerance to $\mathrm{CO}$. To overcome this limit, researchers replaced water with acid as the proton conductor. Using phosphoric acid that has a much lower vapor pressure than water, PEM operating temperatures were increased to $140{ }^{\circ} \mathrm{C}-150^{\circ} \mathrm{C}$ at which point the thermochemical operating limit for Nafion ${ }^{\mathrm{TM}}$ was reached [31] with a marginal improvement in CO tolerance. In another approach to operate Nafion ${ }^{\mathrm{TM}}$ at higher temperatures, some researchers have added solid compounds to Nafion ${ }^{\mathrm{TM}}$ membranes such as heteropoly acids, $\mathrm{SiO}_{2}, \mathrm{WO}_{3}, \mathrm{TiO}_{2}, \mathrm{ZrP}$ while others have used these and similar dopants with alternative membranes such as SPEEK, SPEK, SPSF, and PVDF. Other researchers have filled the Nafion ${ }^{\mathrm{TM}}$ membrane with a thermally stable acid that has high vapor pressure like phosphoric acid. The hydrogen air ambient pressure performance of most of these designs is relatively low with Nafion ${ }^{\mathrm{TM}}$-Teflon- $\mathrm{Zr}\left(\mathrm{H}_{2} \mathrm{PRO}_{3}\right)$ operating at $120{ }^{\circ} \mathrm{C}$ attaining somewhat better performance of $0.6 \mathrm{~V}$ at $200 \mathrm{~mA}$ per square centimeter [32]. Operating these designs on hydrogen/oxygen at higher pressures, 2 to 3 bar results in significant performance increases. Nafion ${ }^{\mathrm{TM}} /$ Mordenite operating on hydrogen/oxygen at ambient pressure achieve $0.6 \mathrm{~V}$ at $280 \mathrm{~mA} / \mathrm{cm}^{2}$ for an operating temperature of $110^{\circ} \mathrm{C}$ but the performance quickly decays with increasing temperature [33,34]. Nafion ${ }^{\mathrm{TM}} / \mathrm{PTA}$ (phosphotungstic acid) operating on hydrogen/oxygen at ambient pressure achieve $0.6 \mathrm{~V}$ at $180 \mathrm{~mA} / \mathrm{cm}^{2}$ for an operating temperature of $120{ }^{\circ} \mathrm{C}$ [35], and Nafion ${ }^{\mathrm{TM}}$-Teflon $\mathrm{Zr}\left(\mathrm{HPO}_{4}\right)$ operating on hydrogen/oxygen at $120{ }^{\circ} \mathrm{C}$ achieved $0.6 \mathrm{~V}$ at $400 \mathrm{~mA} / \mathrm{cm}^{2}$ [32]. While performance is significantly lower than PEM Nafion ${ }^{\mathrm{TM}}$ performance when operated at $80^{\circ} \mathrm{C}$ and ambient pressure with saturated reactants, it is roughly equivalent to the performance of Nafion ${ }^{\mathrm{TM}}$ / phosphoric acid [36], however there are little to no data on the durability of these membranes at fuel-cell operating conditions

Durability of the membrane has been studied by numerous researchers [37-41]. Degradation of Nafion ${ }^{\mathrm{TM}}$ has been separated into the following three mechanisms: chemical, thermal, and mechanical. The fundamental characteristics of each of these mechanisms have been defined and accelerated stress tests (AST) have been defined by DOE and verified for each mechanism [42]. It is generally believed that hydrogen peroxide and its intermediates that are generated during the oxygen reduction reaction in the chemical combination of hydrogen and oxygen reduce the life of PEM by attacking both the end groups and the side chains of the Nafion ${ }^{\mathrm{TM}}$ membrane [6]. While the rate of degradation for each of these mechanisms vary with operating conditions, all of the chemical processes which dominate these reactions become more severe with increasing temperature. While there may be a niche market for PEM operating at a $140{ }^{\circ} \mathrm{C}$, new approaches are required for the vehicular and stationary markets.

Recognizing that a new membrane material was needed to operate at the $180-200{ }^{\circ} \mathrm{C}$, which is required to have sufficient $\mathrm{CO}$ tolerance for the full market, researchers turned to sulfonated aromatic 
polymers, specifically sulfonated polyether eather ketone, (SPEEK) and polyether ketone (SPEK) [43]. Investigations by Kreuer [44] and Ma [45] show that the conductivity of these materials depends strongly on both their degree of sulfonation and their degree of hydration, and, in that regard, they are not significantly better than Nafion ${ }^{\mathrm{TM}}$. A summary of these materials is presented by Scott [46].

While there are many candidate materials that are being evaluated as HT-PEM membranes, polybenzimidazole (PBI) is generally accepted as the "baseline" for both performance and durability for this new generation of PEM [22]. The conductivity of PBI membranes in the pure (unfilled) state is very low at about $10^{-12} / \mathrm{cm}[47,48]$. PBI fills easily with acids, and phosphoric acid is the most frequent dopant but conductivity of phosphoric acid and PBI is influenced by relative humidity, temperature, and acid doping level as reported by Ma [49]. The conductivity of PBI was found to be $0.068 \mathrm{~S} / \mathrm{cm}$ at $200{ }^{\circ} \mathrm{C}$ with a phosphoric acid doping level of $560 \%$ and $5 \%$ relative humidity [50]. This level of conductivity is similar to that of fully hydrated Nafion ${ }^{\mathrm{TM}}$ and sufficient to support the reasonably high current densities required for HT-PEMFC.

In PEM fuel cells, the conductivity of the electrolyte is very important not only for the membrane (cell ionic polarization), but also for the electrode layers. In Nafion ${ }^{\mathrm{TM}}$ cells, the electrolyte is a solid polymer for both the membrane and the catalyst layers. As a solid polymer, this Nafion ${ }^{\mathrm{TM}}$ ionomer provides a stable three phase boundary during fuel-cell operation. In phosphoric acid doped PBI, the ionomer is liquid in both the membrane and the electrode layers. During cell fabrication, PBI bonds with a portion of the acid leaving additional acid free to move. This phenomenon is true for both the membrane and the catalyst layers. This allows the acid to move from anode to cathode and back during cell operation. If acid moves beyond the design limit, the electrode will become flooded resulting in high mass transfer losses. Acid movement is controlled in the cell by controlling the mean pore size and pore size distribution as well as the surface energy of each of the cell complements. Successful design of HT-PEM fuel cells requires the anode gas diffusion layer, the anode catalyst layer, the membrane, the cathode catalyst layer, and the cathode gas diffusion layer to each meet individual and unique requirements for these parameters in order to keep the free phosphoric acid at the proper location in the cell.

Polymer solutions have been prepared in polyphosphoric acid (PPA) and cast into membranes using a sol gel PPA process [51]. Using this technique, PBI polymer doped with phosphoric acid (PA) are easily achieved and have been found to be a promising electrolyte material for high-temperature PEM fuel cells [52]. These membranes are capable of operating at temperatures up to $200{ }^{\circ} \mathrm{C}$ [53]. Moreover, these membranes promise low cost and high performance [52,54]. Early work was done on a variety of PBI identified as mPBI. Testing with this material demonstrated good performance and good stability when operated at temperatures between $130^{\circ} \mathrm{C}$ and $160^{\circ} \mathrm{C}$, however at higher temperatures the stability of this material began to be questioned. For example, in testing and $150^{\circ} \mathrm{C}$ after testing for a $510 \mathrm{~h}$ on hydrogen and oxygen, and no humidification, open circuit voltage decreased from $1.0342 \mathrm{~V}$ to $0.94 \mathrm{~V}$. It was noted that the degradation rate of PBI membranes could be increased as a result of operating conditions $[55,56]$.

In response to the stability concerns, researchers have developed alternative forms of PBI, one on them is identified as AB-PBI with a reported conductivity of $0.08 \mathrm{~S} / \mathrm{cm}$ at $140{ }^{\circ} \mathrm{C}$ and no hydration [57]. Another type, sulfonated PBI has a relatively high conductivity of $0.037 \mathrm{~S} / \mathrm{cm}$ at $170{ }^{\circ} \mathrm{C}$ and zero hydration [58], and Mater and Benicewicz reported another new type of PBI with an impressive conductivity of $0.367 \mathrm{~S} / \mathrm{cm}$ at $180^{\circ} \mathrm{C}$ for a block copolymer consisting of sulfonated PBI segments [59,60]. The longest reported lifetime for a HT-PEM fuel cell is $18,000 \mathrm{~h}$ under steady-state conditions [61]. Since acid power plants have run well over $40,000 \mathrm{~h}$, as demonstrated by United Technologies with their PC 25 fuel-cell power plants, a significant improvement in the longevity of the HT-PEM is required. To achieve this, a focus of research needs to be on developing improved membrane materials [57]. A summary of PBI properties is provided by Mater [62].

In addition to the development and improvements in multiple types of PBI including meta-PBI, para-PBI, and $\mathrm{AB}-\mathrm{PBI}$, alternative materials, most notably cross-linked aromatic polyethers bearing pyridine groups, are being studied. This type of polymer material is composed of an aromatic polyether 
backbone containing mainly chain polar pyridine moieties and that can be doped with phosphoric acid. When the phosphoric acid binds with and is retained in the membrane matrix [63], these materials have a high glass transition temperatures (approximately $270{ }^{\circ} \mathrm{C}$ ) and high thermal stability [64]. Acid doping levels are normally well above $100 \%$ which results in membrane conductivity of $0.05 \mathrm{~S} / \mathrm{cm}$ and free acid which must be managed in a similar manner as was defined in the PBI discussion. Membranes which were produced from pyridine polymers and cross-linked during their impregnation with $85 \%$ phosphoric acid through cation polymerization have been operated between $180^{\circ} \mathrm{C}$ and $220^{\circ} \mathrm{C}$. After demonstrating good performance of $0.6 \mathrm{~V}$ at $200 \mathrm{~mA} / \mathrm{cm}^{2}$ on hydrogen and air with no humidification, stability was demonstrated for $1000 \mathrm{~h}$ with no measurable performance loss. These results demonstrate the potential use for this kind of electrolyte material in HT-PEM fuel cells high [65].

Like Nafion ${ }^{\mathrm{TM}}$, compound membranes based on PBI have been developed by physically modifying the membrane structure with inorganic fillers. This is done to avoid the high acid loadings required to achieve reasonable conductivity which can cause mechanical stability issues with the PBI membranes [66-68]. An avenue to avoid this issue currently being researched involves filling the membrane with solid proton conductors such as solid acids, ionic liquids, and graphite [50,69-78] or hygroscopic materials [79-82].

Pyridine based membranes such as Advent Technologies TPS membrane have also been investigated for HT-PEMFC applications [10-16]. These membranes exhibit glass transition temperatures of $\sim 270^{\circ} \mathrm{C}$ and are thermally stable up to $400^{\circ} \mathrm{C}$. Additionally, Fenton tests results have shown excellent oxidative stability. Advent TPS membranes have been demonstrated in fuel cell applications up to $200{ }^{\circ} \mathrm{C}$ [83-85].

\section{Acid Management}

Fuel cell designs, alkaline, phosphoric acid, and molten carbonate, that depend on an open pore matrix to hold free electrolyte must have extensive, and often expensive, provisions to maintain sufficient electrolyte at the required triple point boundary (TPB) and to maintain sufficient acid in the matrix layer to avoid reactant crossover. Failure to meet these requirements can lead to serious, often catastrophic results.

As these technologies developed, significant effort was devoted to ensure that sufficient electrolyte was maintained in both the matrix and in the electrodes. For the phosphoric acid system, the following five acid loss mechanisms were defined: evaporation, creep, corrosion, contamination, and potential driven migration [20]. These mechanisms were quantified and configurations were devised to accommodate stored acid in a manner that would ensure that the individual cell components retain sufficient acid to ensure successful operation of the stack. Documentation of these design processes as well as the effectiveness of the design modifications are documented in the literature [86-89].

One of the major limitations of previous designs is a very low bubble pressure of the electrolyte matrix, 3-10 inches of water. For this trapped electrolyte design, the electrolyte was held in a silicon carbon matrix by the capillary forces of that matrix. However, the electrolyte can move under electrostatic, capillary, and gravitational forces. In phosphoric acid fuel cells the migration of the electrolyte under electrostatic forces within the cell is generally towards the anode, between the cells the electrolyte moves towards the positive end of the stack, and to a lesser extent the electrolyte moves down under gravitational forces. Electrolyte motion under capillary forces can be in any direction, depending on the mean pore size and the pore size distribution of each of the cell and seal components that are in contact with the electrolyte. Each of the electrolyte loss mechanisms that were identified above, have their own unique characteristics, and while they interact, they can be described and analyzed independently. However, it is the sum of these losses that affect the performance of the stack, and, largely, fuel-cell life.

Addressing these acid loss mechanisms individually, first, the evaporation mechanism is addressed. This acid is lost to flowing reactants, hydrogen and air. The amount of the acid loss is a function of the hydrogen and air flow rates, their temperature at the exit of the cell, time, and to a lesser extent, the design of the flow field. This acid is lost as a vapor and as $\mathrm{P}_{2} \mathrm{O}_{5}$ gas. It then condenses, collects, and 
corrodes downstream components in the stack and the rest of the power plant. Since it is external to the operation of the cell, this type of corrosion does not affect cell performance or cell life. During the normal operation of the power plant, the required power produced is changed almost continuously. With each power change, the fuel and air flow rates change, and, depending on the power control system, the stack exit temperature also changes. As a result, the total acid loss to this mechanism is an integrated average of the losses for each time/temperature load combination. From operating experience, these losses have been found to average approximately 3 ppm [87].

Second, the creep mechanism results in cell acid loss from the edges of the cell to the seals or by flowing down the faces of the stack where it either enters other cells or collects in a pool at the bottom of the manifold. Electrolyte loss to the seals exits the stack across the seals and then, in general, results in corrosion of balance of plant components, as well as structural components. Electrolyte loss to other cells can have a positive or negative effect on the other cells depending on their individual electrolyte levels.

Third, electrolyte loss to corrosion can follow two separate and distinct paths, each with its own consequences. If the electrolyte loss is due to the corrosion of the cell components, the result can be separation of platinum catalyst from the carbon support, which lowers the electrical conductivity of the platinum catalysts particle in the catalyst layer, and therefore electronically makes them electrochemically inert. On the other hand, if the electrolyte reservoir corrodes, both pore size and the pore volume is increased. This results in decreased capillary forces and higher electrolyte storage volume. To the extent that this moves electrolyte away from the triple point boundary (TPB), cell performance is lost. Following the other path, contamination introduced by the fuel and the air streams, can be corroded and produce byproducts that, in addition to using up electrolyte permanently removing it from the electrolyte inventory, can also leave deposits that interfere with fuel, air, water, and electrolyte mass transfer. In general, these result in irrecoverable losses that accumulate over time and eventually either limit cell output power or even lead to stack failure.

Fourth, potential driven migration, also known as electro-osmosis, deals with the movement of the phosphate ion towards the anode and the hydronium ion towards the cathode. At steady-state, since the phosphate ion flux is zero, only the hydronium ion moves [20]. The resistance to this motion is measured as the electrolyte ohmic loss for the cell. During transient operation, both the phosphate ion and the hydronium ion move. This additional phosphate ion flux results in changes in the location of the electrolyte in the electrodes which increase the measured electrolyte ohmic losses during non-steady-state operation. At this point, it should be noted that in phosphoric acid fuel cells, graphitized carbon separator plates are used to keep the electrolyte in each cell. These separator plates are neither $100 \%$ pinhole free nor $100 \%$ corrosion resistant. To the extent that pinholes exist, these electro-osmotic mechanisms for electrolyte transfer move electrolyte through the separator plates due to the potential difference between cells, and due to the negative charge on the phosphate ion. This movement is toward the positive end of the stack [20]. Empirical results from the development of phosphoric acid fuel cells has shown that, at least for the IFC designs, these stacks are capable of operating at design performance with electrolyte "fill" levels that range from $130 \%$ of the electrolyte matrix fill volume to $260 \%$ of that volume. Attempting to run with electrolyte "fill" levels above or below these levels results in an issue ranging from poor performance to catastrophic failure. In general, attempting to run with electrolyte below $130 \%$ of the matrix volume results in portions of the electrodes devoid of sufficient electrolyte to cover the catalyst and local dry spots in the electrolyte matrix. These local dry spots result in reactant crossover which quickly leads to local over temperature due to direct combustion of the fuel and air on the electrodes, and stack failure. This type of failure proceeds very rapidly and is not recoverable. On the other hand, attempting to run with electrolyte "fill" volume above $260 \%$ in any cell, results in very high air side mass transport losses and extremely low cell performance. If this is not recognized and higher power levels are run, to the extent that the cell runs negative, these also lead to cell failure that is not recoverable.

When utilizing HTPEMs such as PBI, acid retention is an important issue as with the older matrices. Acid leaching has been measured by various research groups during stability tests $[90,91]$. 
Pinar and associates researched the addition of $\mathrm{TiO}_{2}$ to $\mathrm{PBI}$ based membranes as a means of improving acid retention [92-94]. The group found that when $2 \mathrm{wt} \% \mathrm{TiO}_{2}$ (average particle size of $1.14 \mu \mathrm{m}$ ) was added to the membrane, leaching tests showed that the $\mathrm{TiO}_{2}-\mathrm{PBI}$ membrane retained five times the acid as a standard PBI membrane [92]. Further testing examined the effect of varying the $\mathrm{TiO}_{2}$ contents between 0 and $16 \mathrm{wt} \%$. It was found that the $2 \mathrm{wt} \% \mathrm{TiO}_{2}-\mathrm{PBI}$ membrane had the highest acid adsorption level ( $2.43 \mathrm{~g}$ acid $/ \mathrm{g}$ membrane), conductivity $\left(0.043 \mathrm{~S} / \mathrm{cm}\right.$ at $150{ }^{\circ} \mathrm{C}$ in $75 \%$ phosphoric acid), and lowest leaching (78\% retained after leach testing) [93]. Stack testing was also performed in later work on a 3 stack, $150 \mathrm{~cm}^{2}$ system [94]. The composite stack was demonstrated to have longer lifetime operation with successful operation past $1100 \mathrm{~h}$ versus standard stacks which failed after less than $225 \mathrm{~h}$ of operation. Acid loss of the composite membrane based system was shown to be only $0.6 \%$ of the total loss during operation.

\section{ORR Catalyst Activity in Free Electrolyte: Alternative Catalyst}

Pt based catalysts are still among the most utilized in the HT-PEMFC and LT-PEMFC community. In the LT-PEMFC community, there have been numerous studies on alternatives to platinum as a catalyst. The reasons for this range from cost issues to stability and performance. Numerous alternative catalysts have been researched for low temperature and high temperature systems, many of which are platinum based alloys such as Pt-Cr, $\mathrm{Pt}-\mathrm{WO}_{3}, \mathrm{Pt}-\mathrm{Cr}-\mathrm{Co}, \mathrm{Pt}-\mathrm{Co}, \mathrm{Pt}-\mathrm{Ni}, \mathrm{Pt}-\mathrm{Fe}$, and $\mathrm{Pt} / \mathrm{RuO}_{2}-\mathrm{SiO}_{x}$ as a few examples. It is worth noting that the presence of phosphoric acid can complicate the implementation of certain novel catalysts due to the oxidation and dissolution at higher temperatures. Alternatively, cost can be reduced by utilizing novel nanoscale manufacturing techniques designed to maximize Pt utilization and significantly reduce loadings, as is the case with Kim et al. [83,84]. In this review, we focus on catalysts used with phosphoric acid and HT-PEMFC systems with the goal of reducing catalyst cost and improving activity for the ORR. For more detail, [95-99] provides a more complete review of catalysts used in polymer electrolyte fuel cell systems.

Earlier work in examining catalyst activity enhancement in phosphoric acid was performed by Luczak et al. on Pt-Co-Cr and Pt-Cr alloys in the patent literature which claimed mass activity enhancements of a factor between 1.5 and 2.5 measured as mA/mg Pt at $0.9 \mathrm{~V}$ [100-103]. However, Beard and Ross [104] as well as Glass [105] did not note improved activity for Pt-Co and Pt-Cr (75\% Pt). As pointed out by Paulus et al. one possible reason for the discrepancy may be related to the fact that reported enhancements occurred on carbon supported platinum while reports of no enhancement were done using bulk alloys [106]. This was resolved when half-cell experiments were performed by Min et al. and they reported improved mass activity for $\mathrm{Pt}-\mathrm{Cr}, \mathrm{Pt}-\mathrm{Co}$, and $\mathrm{Pt}-\mathrm{Ni}$ versus pure $\mathrm{Pt}$ [107]. In their work, the carbon supported Pt based alloys were prepared by the incipient wetness method.

More recent studies have reported the use of alternative catalysts in HT-PEMFC versus the previously mentioned PAFC systems. Arico et al. investigated the stability of $\mathrm{Pt} / \mathrm{C}$ and $\mathrm{Pt}-\mathrm{Co} / \mathrm{C}$ catalysts in a HT-PEMFC system but the system was operated on the lower end of the temperature spectrum at $130^{\circ} \mathrm{C}$ [108]. The testing was performed in Nafion ${ }^{\mathrm{TM}}$ based MEAs as well as sulfuric acid. Accelerated degradation tests showed significant particle sintering with either the Pt or Pt-Co catalysts. The Pt-Co system showed higher stability of the catalyst itself in both the sulfuric acid and MEA systems, however, with the main degradation mechanism being attributed to the carbon support. Degradation tests were performed in 1000 cycles between 0.6 and $1.2 \mathrm{~V} \mathrm{RHE}$ at $20 \mathrm{mV} / \mathrm{s}$.

For higher temperature phosphoric acid based systems, Parrondo et al. studied the effect of using $\mathrm{Pt} / \mathrm{SnO}_{x} / \mathrm{C}$ as a catalyst in a HT-PEMFC [109]. In their work, various $\mathrm{wt} \%$, between $7 \%$ and $24 \%$, were added to the catalyst. Vulcan XC-72R was used as the carbon support and the catalyst along with PBI was airbrushed onto a Sigracet GDL 10BB to produce the GDEs for the cell which were then assembled with a PBI membrane. Additional GDEs were fabricated with pure platinum as the catalyst. The loading in each case was $0.5 \mathrm{mg} / \mathrm{cm}^{2}$. CV and linear sweep voltammetry were used to determine the ECA at $180^{\circ} \mathrm{C}$. It was found that the electrodes containing SnO had comparable ECAs to one containing just platinum, all $<5 \mathrm{mg} / \mathrm{cm}^{2}$. It was also noted that the $\mathrm{OCV}$ of the $\mathrm{SnO}$ containing electrodes was lower 
than that of the pure platinum catalyst which was most likely due to the mixed potential associated with oxidation of $\mathrm{SnO}$, carbon, and impurities. When running polarization curves it was found that the $7 \mathrm{wt} \% \mathrm{SnO}$ catalyst performed the best with the optimum temperature determined to be $180{ }^{\circ} \mathrm{C}$ in the range of $160-200{ }^{\circ} \mathrm{C}$ which produced $0.65 \mathrm{~V}$ at currents of $0.2 \mathrm{~A} / \mathrm{mg}$ Pt. At $180^{\circ} \mathrm{C}$ Impedance spectra were recorded in the activation region to investigate mass transfer near the catalyst surface. The spectra were constant indicating mass transport was similar near the catalyst surface for all the samples. From performance measurements, it was found that increasing the level of $\mathrm{SnO}$ in the catalyst increased mass transport limitations. This was also shown by an increasing diameter of the Nyquist plots presented from $0.3 \Omega-\mathrm{cm}^{2}$ for $7 \mathrm{wt} \% \mathrm{SnO}$ to $0.9 \Omega-\mathrm{cm}^{2}$ for $24 \mathrm{wt} \% \mathrm{SnO}$. The belief was that increased mass transfer resistance was due to the presence of SnO blocking diffusion pathways into the carbon and reducing active surface area. Ohmic resistances of the electrodes increased with increasing $\mathrm{SnO}$ content up to $18 \mathrm{wt} \%$ but then decreased with the highest wt \% of SnO. The reason for this phenomenon was unclear. Durability tests on the cells were run out to $200 \mathrm{~h}$ in which an increasing ohmic resistance was observed. The authors suggested this may be due to phosphoric acid evaporation of movement into the electrodes but no independent study was conducted. Interestingly, polarization curves collected after the durability study showed improved OCV and reduced mass transport limiting current density. It was suggested that this was due to $\mathrm{SnO}$ oxidation to $\mathrm{SnO}_{2}$ leading to reduced effect of the mixed potential while carbon corrosion increased transport losses. The same group also performed a study on Pt-Co for use in a HT-PEMFC system [110]. In this study, Pt-Co alloy particles of varying atomic ratios $(4: 1,3: 1,2: 1$ and 1:1) were prepared by borohydride reduction method. The samples were characterized with XRD, EDX, and SEM. It was found that the lattice parameter was highest for the Pt/C sample $(0.3919 \mathrm{~nm})$ and decreased with increasing Co content $(0.3814 \mathrm{~nm}$ for Pt-Co 1:1 ratio). The Pt-Pt interatomic distance also decreased with increasing Co content with a maximum observed for $\mathrm{Pt} / \mathrm{C}$ of $0.2771 \mathrm{~nm}$ and a minimum observed for Pt-Co/C (1:1 ratio) of 0.2697. CO stripping voltammograms were recorded at room temperature in a glass cell on the prepared catalysts to determine EAS and it was found that $\mathrm{Pt} / \mathrm{C}$ had the highest value $\left(65.2 \mathrm{~m}^{2} / \mathrm{g} \mathrm{Pt}\right)$ with the alloys exhibiting a decreasing value with increasing levels of Co (from 51.4 to $38.3 \mathrm{~m}^{2} / \mathrm{g}$ Pt for the varying Co content). MEAs were constructed with m-PBI membranes and gas diffusion electrodes prepared by airbrushing Sigracet GDL 10BB. The catalyst ink consisted of $40 \mathrm{wt} \%$ metal on carbon (Vulcan XC-72R). Fuel cell testing was performed at 160 and $180^{\circ} \mathrm{C}$ in dry oxygen and hydrogen. Cell performance was highest for the lowest Pt loaded alloys with a gain of $120 \mathrm{mV}$ at $200 \mathrm{~mA} / \mathrm{mg} \mathrm{Pt}$ at $180{ }^{\circ} \mathrm{C}$. This is not surprising considering the lower values of the Pt-Pt interatomic spacing and lattice parameters observed for those alloys. As discussed by Jalan and Taylor [111] and later corroborated by Kim et al. [112] (who utilized their own acid leaching process as well as potential excursion techniques outlined by Gottesfeld and associates [113,114] to roughen the alloy catalyst surface) and Min et al. [107], lower interatomic spacing generally trends towards higher specific activity (see Figure 1).

Durability tests were performed at $180{ }^{\circ} \mathrm{C}$ for $100 \mathrm{~mA} / \mathrm{mg}$ Pt for $50 \mathrm{~h}$ showing good stability.

Zagudaeva and Tarasevich investigated platinum based binary catalysts for HT-PEMFC applications [115]. In their study they examined Pt-Co, Pt-Cr, Pt-Mn, Pt-Ni, Pt-V, and Pt-Fe with a 1:1 atomic ratio. All catalysts were synthesized from catalyst purchased from E-TEK ( $40 \% \mathrm{Pt}$ on carbon black XC-720). Synthesis was performed from organic precursors or salts of d-metals. The catalysts were studied using a model gas diffusion electrode. The GDE was constructed with PTFE-catalyst ink applied to a Toray carbon paper. Polarization curves were recorded in $15 \mathrm{M}$ phosphoric acid at $160{ }^{\circ} \mathrm{C}$. Measurements of the lattice parameter matched well with Rao et al. for Pt/C and Pt-Co/C. The group found that $\mathrm{Pt}-\mathrm{Co}$ and $\mathrm{Pt}-\mathrm{Cr}$ gave the highest mass and specific activity at about twice that of the platinum catalyst they were synthesized from. It is worth noting that in their work, the authors performed an acid rinsing step on the Pt-Co catalyst. Acid washing was performed in $0.5 \mathrm{M}$ sulfuric acid at $60^{\circ} \mathrm{C}$ for 3 to $4 \mathrm{~h}$. These conditions are not completely unlike those employed by Kim et al. [112] (with shorter time and lower concentration but higher temperature) so the effect of surface roughening is not clear. 


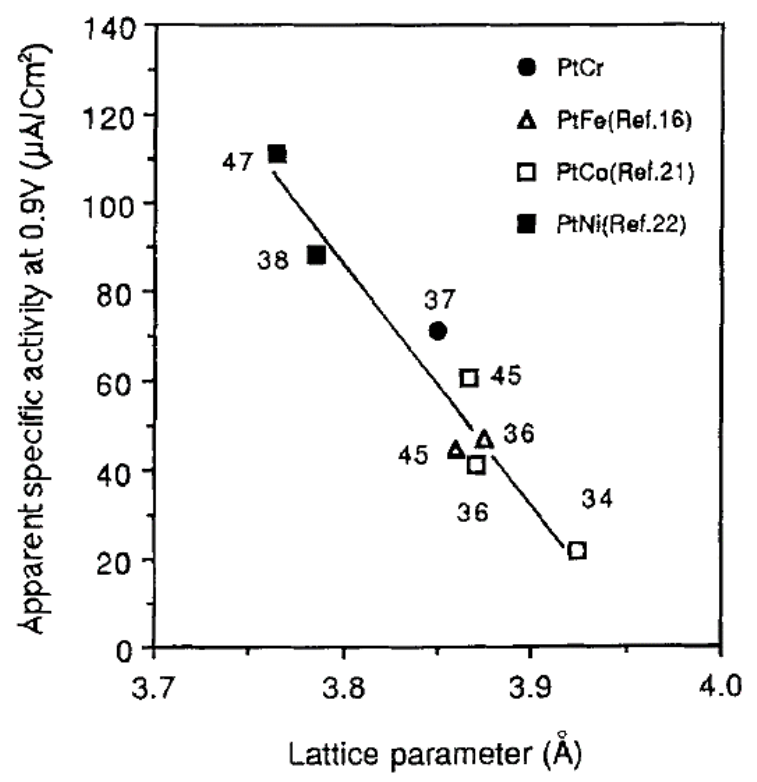

Figure 1. Apparent specific activity vs. lattice parameter for various alloy catalysts (Taken from [112] with permission. Referenced data points correspond to citation list from [112]; Copyright the Electrochemical Society, 1995).

In terms of demonstrated usefulness of alloys in a HT-PEMFC, recent work by Schenk et al. examines Pt-Co [116]. The authors developed a custom catalyst fabrication process designed to fit into a continuous production process and overcome some of the limitations, inefficiencies, and labor intensive steps of alloying metals for fuel cell use. In their process the GDEs were prepared with the catalyst support, which was turbostratic HSAC, with PTFE binder and applied to a wet proofed carbon based GDL via doctor blading. Catalyst material was deposited onto the GDEs via an impregnation technique where the Pt-Co catalyst had a ratio of 1:5. The resulting platinum loading was $1.00 \mathrm{mg} / \mathrm{cm}^{2}$. Activity and stability enhancements were performed by adding a surfactant (Brij-30), as well as performing acid leaching and annealing steps after reduction. Heat treating was performed at $240{ }^{\circ} \mathrm{C}$ in a nitrogen environment to remove any impurities remaining from the synthesis process. The alloy results were compared to commercially available $\mathrm{Pt} / \mathrm{C}$ catalyst from Elcomax $\mathrm{GmbH}$. MEAs were prepared with PBI membranes doped with $85 \%$ phosphoric acid and the resulting $50 \mathrm{~cm}^{2}$ HT-PEMFC single cell was operated at $160^{\circ} \mathrm{C}$ in hydrogen and air. Resulting activity ECSA and activity measurements of the catalysts showed the acid treatment roughened the surface giving a 1.7-fold increase in the specific activity and a 1.6-fold increase in mass activity over $\mathrm{Pt} / \mathrm{C}$. The additional mild heat treatment resulted in a twofold increase in the mass activity over $\mathrm{Pt} / \mathrm{C}$. CV measurements showed the ECSA was almost identical for the Pt/C and acid leached Pt-Co/C samples at about $260 \mathrm{~cm}^{2} / \mathrm{mg}$ $\mathrm{Pt}$ and increased to $310 \mathrm{~cm}^{2} / \mathrm{mg} \mathrm{Pt}$ for the heat treated and acid leached alloy. Accelerated stress tests showed the alloys had the lower degradation rates versus the $\mathrm{Pt} / \mathrm{C}$ sample with the treatments improving those rates. Long term fuel cell tests under constant load $\left(0.2 \mathrm{~A} / \mathrm{cm}^{2}\right)$ were performed over a $600 \mathrm{~h}$ period on the prepared MEAs. The authors found that the cell performances between the $\mathrm{Pt} / \mathrm{C}$ and treated $\mathrm{Pt}-\mathrm{Co} / \mathrm{C}$ based cells were equal confirming the higher activity level of the alloy given that there was less $\mathrm{Pt}$ in the system.

During the $600 \mathrm{~h}$ (see Figure 2) runtime the MEAs prepared with the leached and heat treated alloys showed an initial performance which was lower than the commercial product. As the commercial catalyst based MEA slowly decreased in performance over the $600 \mathrm{~h}$ the alloy based MEA increased and eventually both settled at similar potentials of $604 \mathrm{mV}(\mathrm{Pt}-\mathrm{Co} / \mathrm{C})$ versus $608 \mathrm{mV}(\mathrm{Pt} / \mathrm{C})$.

While this review has focused primarily on catalysts, it is worth mentioning that work is being done examining the support. Vulcan XC-72 is a popular catalyst support typically used in 
the HT-PEMFC literature. Groups such as Zamora and associates have investigated alternative carbon based supports $[117,118]$ as well as silicon carbide [119-121] in phosphoric acid doped PBI based systems. In their works they evaluated the use of several types of carbon based supports including Vulcan XC-72, carbon nanofibers, and carbon nanospheres. They found that thermal and electrochemical stability could be improved using carbon nanospheres because of their higher graphitization degree and compact structure, while carbon nanofibers displayed the highest rates of corrosion due to exposed edge planes [117]. Further evaluation of the carbon nanospheres operating in a HT-PEMFC revealed that, while they exhibit a slightly lower electrical conductivity than Vulcan XC-72, they did not suffer a performance loss relative to the Vulcan XC-72 based system and demonstrate higher stability operating at $160{ }^{\circ} \mathrm{C}$ [118]. The same group also investigated the use of silicon carbide as a catalyst support. Various loadings of silicon carbide were tested $\left(2,4\right.$ and $\left.6 \mathrm{mg} / \mathrm{cm}^{2}\right)$ and compared with a carbon based MPL (microporous layer) [119]. They found that increasing the content of the silicon carbide had a negative effect on the electrical conductivity of the MPL but at 2 and $4 \mathrm{mg} / \mathrm{cm}^{2}$ the electrical resistance was still comparable to the carbon based MPL produced with Vulcan XC-72. In spite of this, the ohmic resistance of the prepared electrode was higher leading to lower cell performance. The tradeoff was a significant boost in thermal and electrochemical stability along with improved mass transport characteristics of the silicon carbide based systems. In later studies, the same group investigated the use of composite titanium silicon carbide $[120,121]$. They found that the composite titanium silicon carbide based system showed cell performance lower but comparable to the Vulcan XC-72 based system with the highest stability when operated at $160^{\circ} \mathrm{C}$.

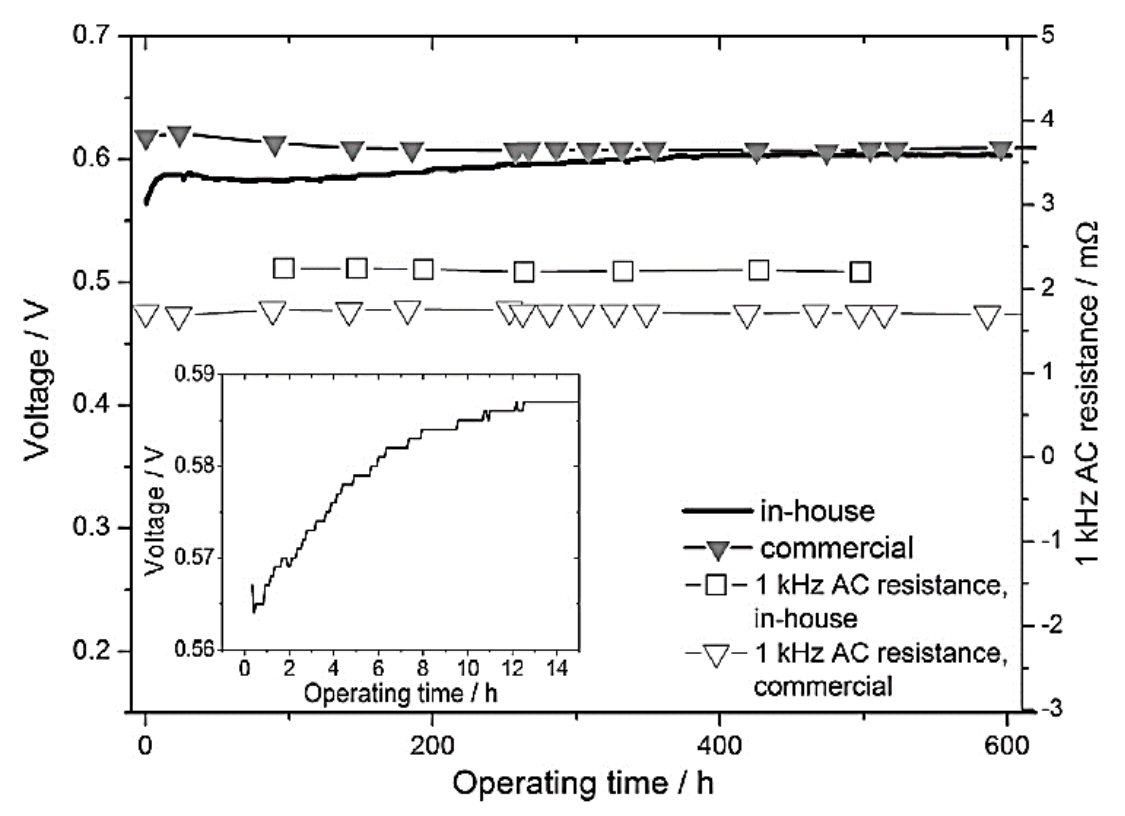

Figure 2. Comparison of cell voltages and the corresponding $1 \mathrm{kHz}$ alternating current $(\mathrm{AC})$ resistances of the leached and heat treated $\mathrm{Pt}-\mathrm{Co} / \mathrm{C}$ based high temperature polymer electrolyte fuel cell (HT-PEM) membrane electrode assembly (MEA) and a commercial HT-PEM MEA during durability testing at $160{ }^{\circ} \mathrm{C}$. The insert shows the first $14 \mathrm{~h}$ of the long term operation of the in-house prepared MEA (Reproduced with permission from [116]; Copyright Elsevier, 2014).

\section{Oxygen Permeability}

A major advantage of HT-PEMFC operation has been cited as the single phase gas transport in the electrode due to the absence of liquid water which exists in LT-PEMFC systems. Despite this advantage, many systems use phosphoric acid, which displays poor oxygen solubility leading to high mass transport losses. In order to establish triple phase boundaries in the electrode, phosphoric acid invariably must be in contact with the catalyst which then requires the oxygen to dissolve and diffuse 
through an acid film to reach the catalyst site. Mass transport issues can be partially alleviated with careful design and targeted wet proofing, but the fundamental mechanism will still involve oxygen permeation through phosphoric acid. In an effort to combat these problems, a number of authors have used turned to additives and alternative electrolytes. Some fundamental research into the effect of using a doped polymer in the electrodes has also been explored. In the case of the additives and alternative electrolytes, it is noted that much of the work has been done in the 1970s and 1980s on phosphoric acid fuel cells. With the emergence of the HT-PEMFC, some of these approaches as well as new ones have been revived.

\subsection{Additives}

In an effort to improve oxygen permeability in phosphoric acid, several authors have employed additives. These additives tend to result in both higher solubility and higher diffusivity of the electrolyte. Early examples of this include the works of Razaq et al. [122] and Gang et al. [123]. Razaq et al. employed perfluorosulfonimide (PFSI) as an additive to phosphoric acid. Those authors measured the solubility and diffusivity in $85 \%$ phosphoric acid and in $84 \%$ PFSI using a microelectrode technique and noted that the solubility was an order of magnitude higher for the PFSI with the diffusivity being five times greater than $85 \%$ phosphoric acid. The potential performance improvement for a fuel cell was tested using a Prototech standard gas-diffusion electrode (10\% Pt on Vulcan XC-72) with varying levels of PFSI with oxygen being supplied at $1 \mathrm{~atm}$. It is noted that at higher wt \% PFSI, $2 \%-4 \%$, there is a flooding behavior of the gas fed electrode leading to a decrease in performance. The flooding behavior is most likely due to a variation in the contact angle with increasing levels of the additive. This flooding behavior was observed to be lower at the $2 \mathrm{wt} \%$ level resulting in a voltage decreasing from 800 to $510 \mathrm{mV}$ over $3 \mathrm{~h}$. At a lower concentration of $0.5 \mathrm{wt} \%$ the performance is markedly improved, with a $70 \mathrm{mV}$ gain at $100 \mathrm{~mA} / \mathrm{cm}^{2}$. The $0.5 \mathrm{wt} \%$ PFSI electrolyte was determined to be below the critical level for electrode flooding based on a $48 \mathrm{~h}$ time invariant measurement. At an even lower wt $\%$ of 0.125 , observed performance increases were still observed but found to be less prominent. It is worth noting that the flooding behavior will change for different electrodes based on the electrode microstructure. This implies the optimal $\mathrm{wt} \%$ of additive will change based on the electrode and additive used. It is important to note that the work of Razaq was performed at $70{ }^{\circ} \mathrm{C}$. Later, they measured the stability of the phosphoric acid-PFSI electrolyte at $150^{\circ} \mathrm{C}$ and found that after $5 \mathrm{~h}$, a substantial amount of the starting $4 \mathrm{wt} \%$ PFSI was lost to evaporation making this particular electrolyte combination unsuitable for high temperature operation.

Following the work of Razaq, Gang et al. tested a variety of additives with phosphoric acid to improve oxygen permeability [123]. These additives were potassium perfluorohexanesulfonate $\left(C_{6}\right.$ salt), potassium nonafluorobutanesulfonate $\left(C_{4}\right.$ salt $)$, perfluorotributylamine $\left(C_{4}\right.$ amine), and silicone oils DC-550 and DC-200 (Si-550 and Si-200 respectively). The additives were added in small amounts, $0.5-3 \mathrm{wt} \%$, to phosphoric acid by mixing at $100{ }^{\circ} \mathrm{C}$. The resulting electrolytes were determined to have different characteristics based on the additive used. In the case of the salts, they dissolved into the acid while the $\mathrm{C}_{4}$ amine and silicone oils formed a separate phase. This phase separation was attributed to the low compatibility with phosphoric acid, which has a strong hydrogen bond network that separates out the $\mathrm{C}_{4}$ amine and silicone oils. Measurements of the solubility and diffusivity were performed using a custom electrochemical cell for varying temperatures and wt $\%$ additive. When considering just the permeability of the modified electrolytes, it was determined that the $1 \mathrm{wt} \%$ of Si-550 was the best with the $1 \mathrm{wt} \% \mathrm{C}_{4}$ amine and $1 \mathrm{wt} \% \mathrm{C}_{4}$ salt a close second. The least improvement was seen with $1 \mathrm{wt} \%$ of the $\mathrm{C}_{6}$ salt and $\mathrm{Si}-200$ but all additives showed an increase in permeability when compared to pure phosphoric acid. Measurements of the modified electrolytes' conductivity indicated that they were virtually unaffected by the modest additive amounts used in the study. Interestingly, it was found by Gang et al. that the salts caused a profound increase in the wettability of the electrolyte on Teflon while the $\mathrm{C}_{4}$ amine and silicone oils did not. Initially, it might be expected that this is related to the fact that the latter group generated emulsions but the PFSI used 
in the work of Razaq et al. also was noted as generating an emulsion at higher concentrations which led to performance loss indicative of flooding. Based on this, it would seem the wettability of the electrolyte containing PFSI was increased relative to pure phosphoric acid. Gang et al. measured fuel cell performance with the modified electrolytes in pure oxygen and hydrogen at $190{ }^{\circ} \mathrm{C}$, see Figure 3 .

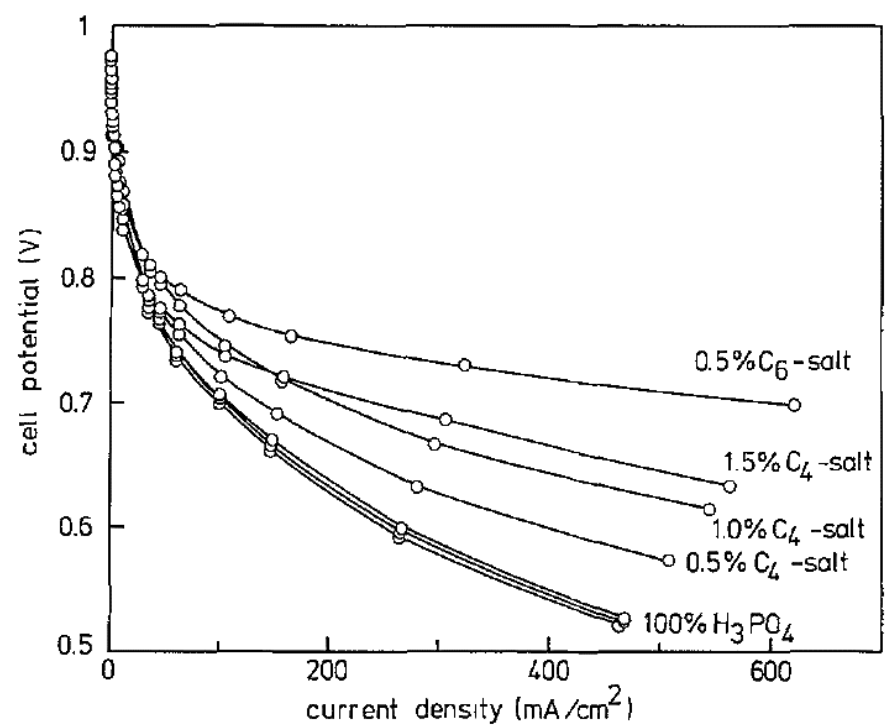

(a)

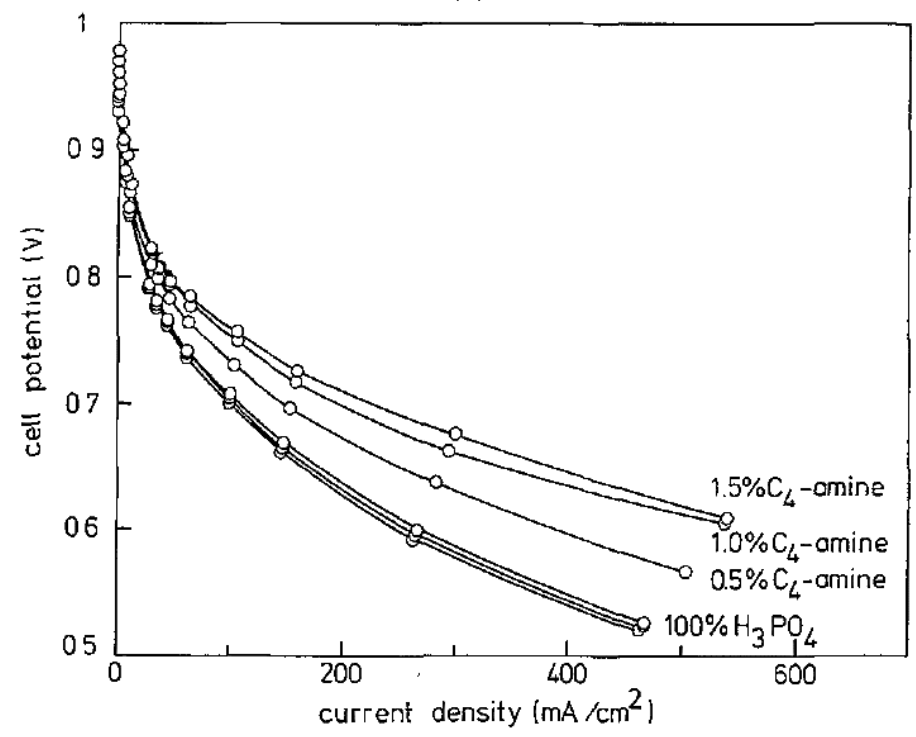

(b)

Figure 3. Cont. 


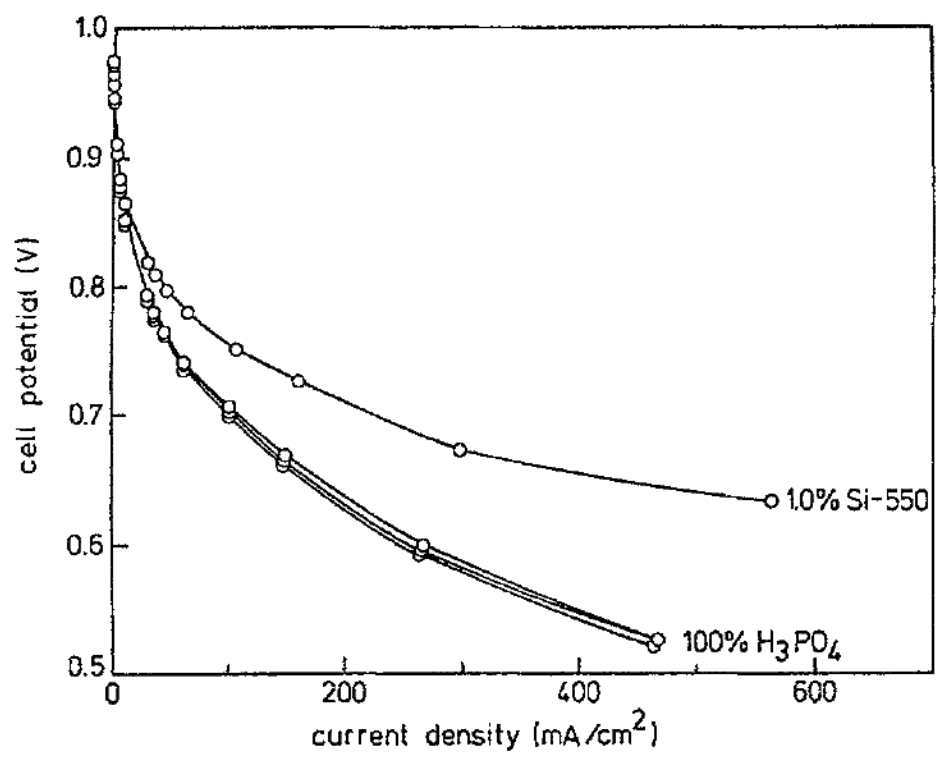

(c)

Figure 3. Polarization curves showing the effect of various wt $\%$ of $\mathrm{C}_{4}$ and $\mathrm{C}_{6}$ salt (a); $\mathrm{C}_{4}$ amine (b); and Si-550 (c) on phosphoric acid fuel cell (PAFC) performance operating at $190{ }^{\circ} \mathrm{C}_{\text {on }} \mathrm{H}_{2} / \mathrm{O}_{2}$ (Reproduced from [123] with permission; Copyright ECS, 1993).

It was determined that all of the additives led to performance increases when added in modest amounts (these amounts varied based on the additive) but then caused a performance loss at higher concentrations. It was hypothesized that the salts' increased wettability led to flooding (which may be combated with electrode microstructure optimization) while the emulsions produced by the $C_{4}$ amine and silicone oils led to a self-assembling blocking layer of increasing thickness at the active sites although this effect was only documented for the amine. Contrary to the measurements of the permeability taken with their custom electrochemical cell, it was found that $0.5 \mathrm{wt} \% \mathrm{C}_{6}$ salt was the best performing modified electrolyte in the fuel cell with $1.5 \mathrm{wt} \% \mathrm{C}_{4}$ salt being second best followed by $1.5 \mathrm{wt} \% \mathrm{C}_{4}$ amine, and $1 \mathrm{wt} \% \mathrm{Si}-550$. Si-200 was not reported in an operational fuel cell. The differences in rankings of best performance were attributed to the different environments of the working fuel cell vs. the electrochemical cell. It was noted that the $\mathrm{C}_{6}$ salt led to a stable performance increase for more than three months. The same research group continued to investigate the addition of the $\mathrm{C}_{6}$ salt over the next few years [124-126].

Another study [126] examined the performance of cells operating with traditional phosphoric acid, phosphoric acid with $\mathrm{C}_{6}$ salt added, Nafion ${ }^{\mathrm{TM}}$ doped phosphoric acid, and PBI doped phosphoric acid. In the study, GDEs were constructed with catalysts prepared with a $40 \mathrm{wt} \%$ PTFE dispersion and tape cast on wet proofed Toray TGH-H-120. The Pt catalyst was distributed on Vulcan XC-72R (weight ratio from 0.1 to 0.2 ) and the loading was $0.5 \mathrm{mg} / \mathrm{cm}^{2}$. The amount of additive was varied and the performance variation was compared to the standard phosphoric acid cell. The optimal level of $\mathrm{C}_{6}$ salt was determined to be roughly $0.2 \mathrm{wt} \%$ which gave a voltage increase of $80 \mathrm{mV}$ in comparison to pure phosphoric acid operating at $190{ }^{\circ} \mathrm{C}$ at 100 and $200 \mathrm{~mA} / \mathrm{cm}^{2}$. Interestingly, the addition of $0.1 \mathrm{wt} \% \mathrm{C}_{6}$ salt resulted in a performance improvement for the cell despite Bjerrum's group measuring a loss in their study from 1995. It is not clear why a performance gain was measured in this instance since the electrode manufacturing method was referenced from the previous study but PTFE loadings or acid doping levels may have been adjusted to mitigate flooding.

Following these initial studies, the topic of additives for improved oxygen permeability remained largely undiscussed in the literature until the last ten years. In 2009, Hong et al. investigated the use of ammonium trifluoromethanesulfonate (ATFMS) in a HT-PEMFC utilizing phosphoric acid doped 
polybenzoxazine-based membrane operating at $150^{\circ} \mathrm{C}$ [127]. TGA measurements found the additive was stable up to $200^{\circ} \mathrm{C}$. It was shown with RDE measurements that the modified electrolyte displayed improved ORR activity and oxygen solubility. The optimum level of ATFMS was determined to be between 5 and $10 \mathrm{wt} \%$ with $20 \mathrm{wt} \%$ giving similar performance to that of $100 \%$ phosphoric acid due to increased impedance. Electrochemical measurements of the diffusivity and solubility showed a modest increase in solubility of the modified electrolyte versus pure phosphoric acid, only 1.5 times higher, and a slight decrease in diffusivity. Overall, a performance increase was observed over the entire current density range $\left(\sim 30 \mathrm{mV}\right.$ at $\left.200 \mathrm{~mA} / \mathrm{cm}^{2}\right)$ and stable operation was documented for over $600 \mathrm{~h}$.

Mamlouk and Scott performed two studies on optimizing PBI based HT-PEMFCs in which the $\mathrm{C}_{6}$ salt from the work of Gang et al. was employed [128,129]. In both studies, the same amount, $0.5 \mathrm{wt} \%$, was added. In the initial study [128], it was noted that a substantial performance improvement was obtained. The performance increased from $100 \mathrm{mV}$ for pure phosphoric acid at $100 \mathrm{~mA} / \mathrm{cm}^{2}$ to $500 \mathrm{mV}$ with the additive when operated on air at $150{ }^{\circ} \mathrm{C}$. Additionally, while a limiting current density of $180 \mathrm{~mA} / \mathrm{cm}^{2}$ was obtained on oxygen without the additive, no limiting current density was observed when the additive was employed. The same group attempted to add the same level of the $C_{6}$ salt in a later article [129] which resulted in a reduction in performance of the cell over the whole range of current densities. The cells were operated using both air and oxygen at $120^{\circ} \mathrm{C}$. These cells were constructed with GDEs using the same carbon cloth and microporous layer (H2315 T10AC1) with 50\% Pt/C catalyst from Etek $\left(0.4 \mathrm{mg} / \mathrm{cm}^{2}\right)$ on the cathode, but in the latter scenario, a $20 \%-40 \%$ content of PTFE was used rather than PBI in the electrodes. The authors noted the decreased surface tension caused by the surfactant led to flooding. This result is consistent with the observations of Gang and illustrates the importance of choosing the correct additive weight and type for a given fuel cell electrode as well as careful tailoring of the electrode microstructure.

\subsection{Alternative Electrolytes}

Another approach to mitigating problems with the low oxygen permeability of phosphoric acid, many researchers have investigated alternative acids. It is worth noting that when discussing "alternative acids" different research papers refer to them as replacements or substitutes to phosphoric acid. However, many of these research papers report on studies of the acid properties with few research papers using them in a functioning fuel cell.

One of the earliest examples in these alternative acids was the work of Appleby and Baker [17] and Adams et al. [130] who investigated the potential use of trifluoromethane sulfonic acid (TFMSA). For RDE studies performed at low concentrations both authors noted a strong improvement in performance which were originally believed to be related to reduced phosphate anion adsorption. This same acid was researched by later $[18,19,131]$ groups with the prevailing theory that, for concentrations and temperatures most pertinent to fuel cell operation, the improved rate of oxygen reduction in TFMSA is due to increased solubility and diffusivity of oxygen as well with minor gains due to reduced phosphate adsorption. However, despite the advantages associated with TMFSA, several problems including high vapor pressure, ability to wet Teflon at higher concentrations, and lower ionic conductivity makes implementing TFMSA in a real fuel cell problematic $[132,133]$. As such, continuing efforts have sought the use of alternative electrolytes which can offer the benefits of TFMSA without the negative consequences.

\subsection{Effect of Doped Ionomer}

Improved oxygen solubility has been reported for PBI by Liu et al. [134]. The authors investigated the ORR on platinum interfaced with PBI doped by phosphoric acid under at high temperature for various acid doping levels and relative humidity by means of a micro band electrode technique. Their group reports that the oxygen solubility in PBI is four times higher than can be expected in concentrated phosphoric acid at $150{ }^{\circ} \mathrm{C}, 10 \% \mathrm{RH}$ (equating to about $95 \mathrm{wt} \%$ phosphoric acid). This behavior is explained as being related to the PBI casting technique. When the PBI is cast, a 
trifluoroacetic acid (TFA) solution is used. As the crystallization begins and some of the TFA that was left in the membrane evaporates causing the membrane to shrink and bend the microfibrils. The result is a membrane under elastic stress that then puts the doped phosphoric acid under negative hydroelastic stress and creates a scenario where the membrane tries to expand by absorbing surrounding molecules such as water vapor and oxygen. The amorphous phosphoric acid in the membrane then absorbs higher levels of oxygen. In the case of oxygen diffusivity it was found that it follows a typical Bruggeman behavior with diffusivity increasing with volume fraction of amorphous phosphoric acid in the PBI this is indicative that the phosphoric acid is the primary diffusion pathway with no influence from the PBI except to act as a physical barrier.

\section{Phosphate Adsorption}

When phosphoric acid is used as an electrolyte, it has been widely documented that the phosphate anion is strongly adsorbed on the surface of the platinum catalyst. This has inspired research on alternative acids which exhibit weakly adsorbing behavior on platinum as well as on additive materials which can effectively block the phosphate adsorption. This section details some of the work which has been done for phosphoric acid cells as well as newer work being done specifically for HT-PEMFC.

\subsection{Additives}

The use of additives in phosphoric acid has been documented as improving oxygen permeability by increasing either solubility or diffusivity, or both, as discussed in Section 5.1. Another documented advantage of many of these additives is the reduction of phosphate adsorption. In the work of Razaq they mention the formation of a "dry cave" around the surface of the catalyst [122]. In their work, this dry cave is created by a physically adsorbed layer of the PFSI additive used which results in a locally higher concentration of oxygen and a lower concentration of phosphoric acid and water. As a result, the phosphate anions of the phosphoric acid are physically blocked. Gang et al. later identified a similar phenomenon for the silicone oils and $C_{4}$ amine additives [123]. In both works, the authors discuss how the strong hydrogen bond network of the phosphoric acid tends to segregate the additives which physically adsorb onto the surface of the catalyst. In the work of Gang, this is described as an "oasis" but the mechanism is the same. Figure 4 shows a sketch of the dry cave behavior in the electrode.

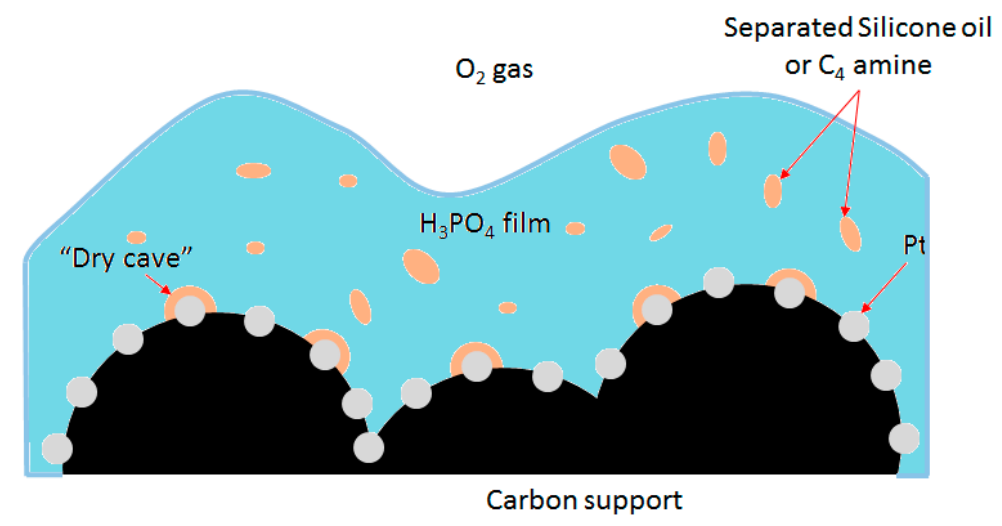

Figure 4. Sketch of electrolyte coated catalyst. The phosphoric acid film contains a segregated additive which provides higher oxygen permeability and a physically adsorbed layer on the Pt surface to block phosphate adsorption.

Another approach to additives for combating phosphate adsorption was taken by Kwon et al. [135]. In their work, calix[4]pyrrole was added to the cathode of the MEA by mixing with the catalyst ink. This was done because evidence in the literature showed that calix[n]pyrroles has strong anion receptors. The motivation was to include calix[4]pyrrole in the electrode to interact with the phosphate 
anions, thus increasing the available active area of the platinum catalyst. In that study, TGA, RDE, and MEA tests are reported. TGA results show the onset of thermal decomposition occurring at $234{ }^{\circ} \mathrm{C}$ making this material suitable for HT-PEMFC operation. RDE studies were performed on samples made by two methods; the thin film RDE method (TFRDE) and the thin active layer RDE method (TALRDE). TALRDE was used to confirm an increase in surface area of platinum available when calix[4]pyrrole is used for 3, 20 and $38 \mathrm{wt} \%$ phosphoric acid in a platinum loading of 60 and $220 \mu \mathrm{g} / \mathrm{cm}^{2}$ platinum loading. The measured utilization by the CO adsorption method increases from $70 \%$ to $77 \%$ at the lower loading and $58 \%$ to $69 \%$ at the higher loading for $38 \mathrm{wt} \%$ phosphoric acid. Linear scans were performed and the effects of calix[4]pyrrole were shown to be related to phosphate adsorption rather than an increase in ORR The optimum level of platinum to calix[4]pyrrole was determined to be 1:0.24 wt ratio. It is noted however, that high levels of the calix[4]pyrrole will eventually reduce performance due to electrical an insulating behavior. As such, the "corrected platinum loading" versus the weight ratio of calix[4]pyrrole is determined by using the $\mathrm{Pt}+\mathrm{CP}$ mass rather than $\mathrm{Pt}$ mass in calculating apparent platinum loading of the electrode. MEA performance was measured for a cell temperature of $150{ }^{\circ} \mathrm{C}$ with dry $\mathrm{H}_{2}$ and air on three different cathode types; $1.1 \mathrm{mg} / \mathrm{cm}^{2}$ platinum, $1.1 \mathrm{mg} / \mathrm{cm}^{2}$ platinum/calix[4]pyrrole, and $1.6 \mathrm{mg} / \mathrm{cm}^{2}$ platinum. It was found that the electrode containing the calix[4]pyrrole outperformed the platinum based cell of the same loading over the whole range of current densities (with a performance improvement of $30 \mathrm{mV}$ at $200 \mathrm{~mA} / \mathrm{cm}^{2}$ ). The calix[4]pyrrole MEA performed almost identically to the higher loaded platinum MEA.

\subsection{Alternative Acids}

Using TFMSA as a model compound, researchers developed alternative electrolytes to amplify the benefits which made TFMSA attractive. An early example of this was presented by Striebel et al. who investigated an alternative to TMFSA, tetrafluoroethane-1,2-disulfonic acid (TFEDSA) using RDE [136]. The motivation here was to overcome the high vapor pressure and wetting behavior of TFMSA with Teflon. RDE measurements performed at $25^{\circ} \mathrm{C}$ on platinum showed similar kinetics observed for the same $\mathrm{pH}$ over the $1-0.65 \mathrm{~V}$ potential range for identical overvoltages between the two acids but it is unclear whether TFEDSA would be subject to the same changing behavior when applied to a real fuel cell operating condition. Ross and associates also investigated alternative compounds to TFMSA noting the undesirable properties it had for fuel cell operation [137]. Using the TFMSA as the model compound the authors studied perfluoroalkane disulfonic acids $\left[\mathrm{HSO}_{3}(\mathrm{CF} 2)_{n} \mathrm{SO}_{3} \mathrm{H}\right]$ with $n=2,4,6$. But humidification requirements set by conductivity issues with the hydrate acids set an operating temperature limit of $100{ }^{\circ} \mathrm{C}$ which puts it below the threshold described in this review for HT-PEMFC.

Kanamura et al. investigated the use of perfluoro-ethylene-1,2-bis-phosphonic acid [138], where $85 \mathrm{wt} \%$ perfluoro-ethylene-1,2-bis-phosphonic acid and phosphoric acid were tested with a RHE reference electrode and a platinum foil counter electrode. The resulting CV measurements were performed at $22{ }^{\circ} \mathrm{C}$ and showed strong hydrogen adsorption peaks on platinum with the Perfluoroethylene-1,2-bis-phosphonic acid versus the phosphoric acid which indicated the Perfluoroethylene-1,2-bis-phosphonic acid was not strongly adsorbing. However, when measurements of solubility and diffusivity of oxygen at $22{ }^{\circ} \mathrm{C}$ were performed using a potential-step chronoamperometry technique it was found that the overall permeability was lower for the Perfluoro-ethylene1,2-bis-phosphonic acid. This was alleviated at higher temperatures but ultimately fuel cell durability tests on operating electrodes showed that, after $500-600 \mathrm{~h}$ at $200{ }^{\circ} \mathrm{C}$, the performance reverts to that the level of standard phosphoric acid due most likely to the decomposition of the perfluoroethylene-1,2-bis-phosphonic acid.

More recently, with HT-PEMFC applications in mind Heider et al. investigated the use of perfluoroalkyl-phosphonic and bis(perfluoroalkyl) phosphinic acids with different lengths of perfluoroalkyl chains (C2 and C4) [139]. Practical synthesis of these acids was developed in a collaboration between Merck KGaA and the Willner research group [140-142]. They exhibit high oxygen solubility and proton conductivity under anhydrous conditions. Heider performed 
CV of RDE measurements using a platinum disk electrode and glass cell with a three electrode setup. They started with a host solution of perchloric acid and added acids up to $1 \mathrm{mM}$. In these experiments, pentafluoroethyl-phosphonic acid (PFEPA), nonafluorobutyl-phosphonic acid (NBPA), bis(pentafluoroethyl)-phosphinic acid (BPPA), bis(nonafluorobutyl)-phosphinic acid (BNPA), and phosphoric acid were tested. It was found that the ORR activity increased with each successive substitution of hydroxyl groups by perfluoroalkyl chains while the length of the chains themselves did not have a major impact. This was explained by the number of proton donating groups being reduced and acidity increased. The reason for this ORR boost was associated with a weakening adsorption behavior. In a simple model of the adsorption mechanism, it was suggested that the adsorption was attributed to the number of negatively charged hydroxyl groups in the given species. This leads to the observed doubling of the ORR activity for perfluoroalkyl-phosphonic acids, and a 5 times increases for perfluoroalkylated phosphinic acids. In another study, Heider evaluated trifluoromethylphophonic acid (TFMPA) and PFEPA through a variety of techniques including CV, RDE, EIS, and in situ FTIR [143]. Measurements of the ORR were performed with RDE as well as in a dual thin-layer flow cell. The general conclusion is that the substitution of one hydroxyl group in phosphoric acid by a perfluoroalkylated chain significantly reduces tendency for adsorption but the production of hydrogen peroxide is increased, specifically with the PFEPA. CV measurements at $80^{\circ} \mathrm{C}$ in argon purged electrolyte up to $1 \mathrm{mM}$ acid show a shift in the half wave potential of $\mathrm{Pt}-\mathrm{O}$ formation of up to $42 \mathrm{mV}$ for phosphoric acid versus only $25 \mathrm{mV}$ for TFMPA. RDE ORR measurements of $1 \mathrm{mM}$ TFMPA and phosphoric acid in $0.5 \mathrm{M}$ perchloric acid at $0.95 \mathrm{~V}$ show that the activity for TFMPA is double that for phosphoric acid. It is argued that the addition of the trifluoromethyl group results in a decrease in proton donating groups while also increasing acidity. The group notes no significant change electrocatalytic activity with increasing alkyl chain length. This observation lends evidence to the hypothesis that the main reason for lower adsorption is reducing the number of hydroxyl groups. The ORR activity was also investigated in the dual thin layer chemical flow cell which allowed for simultaneous detection of hydrogen peroxide via FTIR. It was noted that the results closely agreed with the RDE measurements. EIS measurements were performed on TFMPA and phosphoric acid up to $1 \mathrm{mM}$ concentration between 20 and $80^{\circ} \mathrm{C}$. The results showed TFMPA had a lower charge transfer resistance. The same group investigated the use of TFMPA and PFEPA in an actual fuel cell system [144]. These acids were each added to phosphoric acid at $20 \mathrm{wt} \%$ and used in a HT-PEMFC. Before demonstrating the performance in a fuel cell, TGA, conductivity, doping levels, and wettability measurements were taken. TGA results suggested a reduced effect of dehydration in the presence of the additives and that the mixed electrolytes were stable up to $20{ }^{\circ} \mathrm{C}$. Conductivity measurements were performed by loading a PEEK mesh grid with the acid mixtures. The phosphoric acid had the highest conductivity at $160{ }^{\circ} \mathrm{C}$ of $0.084 \mathrm{~S} / \mathrm{cm}^{2}$, followed by TFMPA at $0.075 \mathrm{~S} / \mathrm{cm}^{2}$, and finally $0.07 \mathrm{~S} / \mathrm{cm}^{2}$ for the PFEPA. As was the case in the literature with other fluorinated compounds, the acids investigated here had a higher degree of wettability with PTFE. Decreases of $40 \%-60 \%$ were observed in the contact angle with the addition of the TMFPA and PFEPA. Finally, doping levels in AB-PBI membranes obtained from Fumatech was reported. With phosphoric acid as a baseline ( $370 \mathrm{wt} \%$ doping), it was found that the doping level increased with PFEPA to $493 \mathrm{wt} \%$ and decreased with TFMPA to $268 \mathrm{wt} \%$. Cells for testing were constructed with GDEs prepared by spraying a catalyst slurry onto a Freudenberg H2315 C2 GDL. The catalyst used was a $20 \mathrm{wt} \% \mathrm{Pt} / \mathrm{C}$ from Heraeus. The final catalyst layer loading was $1 \mathrm{mg} / \mathrm{cm}^{2}$ with $10 \mathrm{wt} \%$ PTFE. The AB-PBI membrane was used in these tests and doped with $370 \mathrm{wt} \%$ phosphoric acid. The electrodes were independently sprayed with the electrolyte mixes such that the final wt \% of the cell was 20 for the TMFPA and PFEPA. The cells were operated at $160{ }^{\circ} \mathrm{C}$ on hydrogen and air. In the cases of both electrolyte mixes, a performance increase was observed versus standard phosphoric acid. The phosphoric acid cell generated a maximum current density of $180 \mathrm{~mW} / \mathrm{cm}^{2}$ while the ones using TFMPA and PFEPA generated 270 and $240 \mathrm{~mW} / \mathrm{cm}^{2}$, respectively. Figure 5 shows the resulting performance curves obtained by Mack et al. 


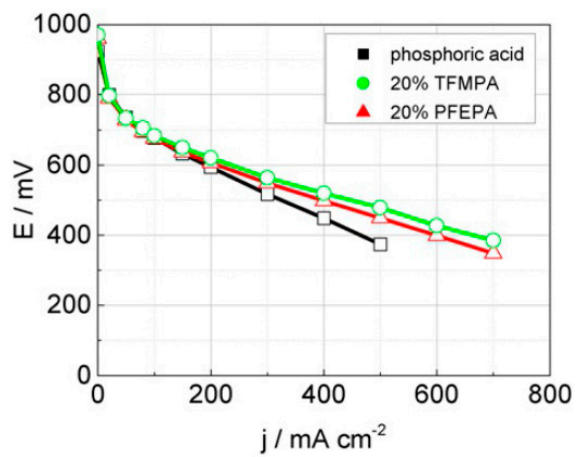

(a)

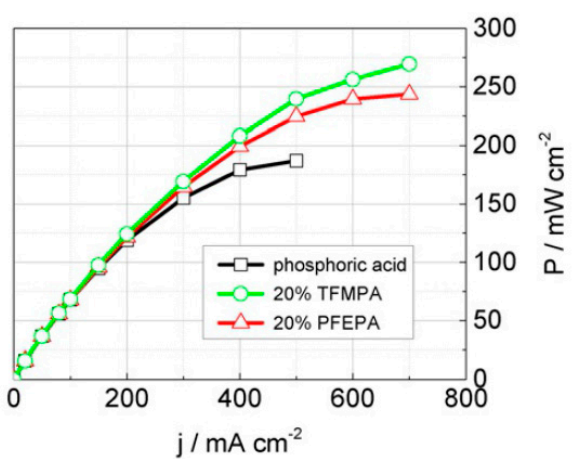

(b)

Figure 5. Polarization curves (a); and power density curves (b) of the HT-PEMFCs with different cathode electrode doping: concentrated phosphoric acid, PFEPA, and TFMPA additives (Reproduced from [144] with permission; Copyright John Wiley and Sons, 2016).

EIS was also conducted and lower charge transfer resistances were reported for the new acid compounds indicating reduced phosphate adsorption as expected. The charge transfer resistance was $520 \mathrm{~m} \Omega / \mathrm{cm}^{2}$ for phosphoric acid, $280 \mathrm{~m} \Omega / \mathrm{cm}^{2}$ for TFMPA, and $400 \mathrm{~m} \Omega / \mathrm{cm}^{2}$ for PFEPA. While the central focus of using these acids is reduction of phosphate adsorption, it is noted that changes in wetting behavior and oxygen solubility will also have an effect on performance.

\subsection{Impact of Catalyst}

As discussed in this review, many authors have investigated the effect of phosphate adsorption on $\mathrm{Pt} / \mathrm{C}$ catalyst but there has been limited systematic study on the behavior with different catalyst materials. A few studies have been published investigating the phosphate adsorption behavior for different catalyst types. Lee et al. investigated phosphate adsorption on both Pt-Co alloys and $\mathrm{Au}_{\text {core }}-\mathrm{Pt}_{\text {shell }}$ catalysts [145]. The Pt-Co catalysts were obtained from Tanaka Kikinzoku Kogyo K.K., (Tokyo, Japan) (45.6 wt \% Pt/C and $\left.51.6 \mathrm{wt} \% \mathrm{Pt}_{3}-\mathrm{Co} / \mathrm{C}\right)$ and BASF Fuel Cell GmbH $(40 \mathrm{wt} \% \mathrm{PtCo} / \mathrm{C})$ while the core shell catalysts $(59.7 \mathrm{wt} \%$ ) were made in house. Phosphate adsorption behavior was examined using $\mathrm{CV}$ and $\mathrm{N}_{2} \mathrm{O}$ reduction analysis. $\mathrm{CVs}$ were taken in perchloric acid and compared with $0.1 \mathrm{M}$ phosphoric acid added. The CV results showed that the presence of increasing Co in the alloy catalysts led to increasing levels of phosphate adsorption. The core shell catalyst however, showed less adsorption compared to the pure $\mathrm{Pt} / \mathrm{C}$ catalyst. Interestingly, the measured $\mathrm{Pt}$ lattice parameters reported for the catalysts trend towards lower higher values for higher phosphate adsorption. Further analysis using $\mathrm{N}_{2} \mathrm{O}$ adsorption showed phosphate adsorption occurred on terrace sites instead of step edges for the alloys. The measured $\mathrm{N}_{2} \mathrm{O}$ reduction current when adding phosphoric acid with the core shell catalyst showed the smallest decay. This was believed to be related to the underlying Au but detailed explanations were not provided. ORR kinetic currents were measured at $0.9 \mathrm{~V}$ and normalized against metal mass and $\mathrm{Pt}$ mass. For the metal mass the $\mathrm{Pt}_{3}-\mathrm{Co} / \mathrm{C}$ catalyst had the highest current of about $10 \mathrm{~A} / \mathrm{g}_{\text {metal }}$ with the core-shell following at about $8 \mathrm{~A} / \mathrm{g}_{\text {metal }}$. When the normalization is made against $\mathrm{Pt}$ mass however the best performance is given by the core shell catalyst at roughly $16 \mathrm{~A} / \mathrm{g}_{\mathrm{Pt}}$ versus the $\mathrm{Pt}_{3}-\mathrm{Co} / \mathrm{C}$ of roughly $11 \mathrm{~A} / \mathrm{g}_{\mathrm{Pt}}$.

$\mathrm{He}$ et al. also examined the effects of phosphate adsorption on alloyed catalysts, specifically Pt-Ni alloys [146]. The Pt-Ni alloys investigated were obtained from BASF Fuel Cells and compared to Pt/C catalysts from the same source. The phosphate adsorption behavior was studied using CV, RDE, and in situ X-ray adsorption spectroscopy. It was found that $\mathrm{Pt}-\mathrm{Ni} / \mathrm{C}$ catalyst with smaller particle size showed better kinetic performance than $\mathrm{Pt} / \mathrm{C}$ in $0.1 \mathrm{M}$ perchloric acid. CO stripping was used to identify the surface element ratios and it was found that Ni occupied about $1 / 4$ of the sites reducing the three-fold $\mathrm{Pt}$ sites which were proposed to be the preferential sites for phosphate adsorption by Tanaka et al. [147]. 
While the effect of phosphate adsorption has been shown to be important for different catalyst types by the aforementioned authors it is important to note that conclusions may be affected with the addition of the various additives or alternative acids discussed in this section. For example, it is possible that the $\mathrm{Pt}_{3}-\mathrm{Co} / \mathrm{C}$ catalyst will outperform the Au core-Pt shell catalyst if acids or additives, which significantly reduce the adsorption behavior, are employed. Additional research should be focused on the combined effects of these parameters.

\section{Conclusions}

Despite the advantages of HT-PEMFCs versus LT-PEMFCs, there are major roadblocks which prevent them from being a viable alternative. The widespread use of phosphoric acid doping leads to the inevitable presence of free electrolyte in the fuel cell electrodes. However, this free electrolyte is crucial to cell performance as it acts as the ionic phase conductor in the electrode. This leads to issues that have been plaguing the phosphoric acid fuel cell (PAFC) community for decades, issues including poor oxygen activity in phosphoric acid, low oxygen permeability in phosphoric acid, phosphate adsorption onto the catalyst surface, and electrolyte movement within the cell. Despite the challenges, resolution pathways have been explored to address each of these issues including alternative catalysts, additives, and alternative acids. In this review, we have identified and quantified performance improvement mechanisms that are defined in the literature. If these are additive, they could result in performance improvements up to $300 \%$. In the areas of improved catalysts, $\mathrm{Pt}-\mathrm{Co}$ has demonstrated better activity than Pt based catalysts in HT-PEMFC operation with good stability. Alternative supports also investigated in the literature such as carbon nanospheres and composite titanium silicon carbide show promise in improving electrode stability even further. With recent trends in the literature it seems unlikely that free electrolyte based systems will be replaced any time soon with phosphoric acid doped membranes such as PBI still being the standard. As such, issues of permeability and phosphate adsorption on the catalyst are a concern. Additives such as perfluorotributylamine and silicone oils have demonstrated improved performance in traditional phosphoric acid systems without affecting the wettability of the electrodes (which may or may not have a negative effect on performance depending on electrode design) but have seen limited use in HT-PEMFC systems. Additives such as calixpyrrole or alternative acids such as trifluoromethylphophonic acid can significantly reduce the level of phosphate adsorption. While all of these approaches show promise in HT-PEMFC systems, additional research is required to determine the specific combinations of these modifications, materials, additives, and dopants that are compatible, and then verify the performance improvement that is attainable. For example, Pt-Co has been determined to have stronger adsorption behavior in phosphoric acid systems. It is then natural to question how well the previously investigated materials to reduce phosphate adsorption would behave with these catalysts. It is possible that the already promising performance of the Pt-Co catalysts can be greatly improved further by taking steps to reduce phosphate adsorption. Silicone oil has been discussed as creating a "dry cave" helping to prevent phosphate adsorption while also improving permeability. Trifluoromethylphophonic acid also reduces phosphate adsorption and there is mention of potential permeability improvements as well. The question here is whether a combination of these two materials leads to an advantage in terms of performance. Alternatively, calixpyrrole added to the electrode reduces phosphate adsorption but does not affect permeability, while perfluorohexanesulfonate improves permeability but is not expected to have the same effect on adsorption. The benefits of these two materials may be additive. As such, further research examining the possibility of combining positive additives, alternative acids, and supported catalysts is recommended with a focus on finding symbiotic relationships between materials to achieve the highest overall performance possible.

Acknowledgments: The authors would like to acknowledge the financial support of National Science Foundation, NSF-GOALI (contract No. CCM1-1265893).

Author Contributions: T.D.M., L.B. and R.M. participated in outlining the scope of the review and assisted in drafting the manuscript. All authors read and approved the manuscript prior to submission. 
Conflicts of Interest: The authors declare no conflict of interest. The founding sponsors had no role in the design of the study; in the collection, analyses, or interpretation of data; in the writing of the manuscript, and in the decision to publish the results.

\section{References}

1. Kreuer, K.D. On the development of proton conducting polymer membranes for hydrogen and methanol fuel cells. J. Membr. Sci. 2001, 185, 29-39. [CrossRef]

2. Yang, C.; Costamagna, P.; Srinivasan, S.; Benziger, J.; Bocarsly, A.B. Approaches and technical challenges to high temperature operation of PEMFC. J. Power Sources 2001, 103, 1-9. [CrossRef]

3. Paddison, S.J. Proton conducting mechanism at low degree of hydration in sulfonic acid-based polymer electrolyte membranes. Ann. Rev. Mater. Res. 2003, 33, 289-319. [CrossRef]

4. Li, Q.; He, R.; Jensen, J.O.; Bjerrum, N.J. Approaches and recent development of polymer electrolyte membranes for fuel cells operating above $100^{\circ} \mathrm{C}$. Chem. Mater. 2003, 15, 4896-4915. [CrossRef]

5. Zhang, J.; Xie, Z.; Zhang, J.; Tang, Y.; Song, C.; Navessin, T.; Shi, Z.; Song, D.; Wang, H.; Wilkinson, D.P.; et al. High temperature PEM fuel cells. J. Power Sources 2006, 160, 872-891. [CrossRef]

6. Shao, Y.; Yin, G.; Wang, Z.; Gao, Y. PEMFC from low temperature to high temperature: Material challenges. J. Power Sources 2007, 167, 235-242. [CrossRef]

7. Gasteiger, H.A.; Mathias, M.F. Fundamental research and development challenges in Polymer Electrolyte Fuel Cell Technology. Proton Conduct. Fuel Cells III Proc. Electr. Soc. Ser. 2002, 2005, 1-24.

8. Dai, W.; Wang, H.; Yuan, X.-Z.; Martin, J.-J.; Yang, D.; Qiao, J.; Ma, J. A review on water balance in the membrane electrode assembly of PEMFC. Int. J. Hydrog. Energy 2009, 34, 9461-9478. [CrossRef]

9. Subianto, S. Recent advances in polybenzimidazole/phosphoric acid membranes for high-temperature fuel cells. Polym. Int. 2014, 63, 1134-1144. [CrossRef]

10. Morfopoulou, C.; Andreopoulou, A.K.; Kallitsis, J.K. The effect of structural variations on aromatic polyethers for high-temperature PEM fuel cells. J. Polym. Sci. A 2011, 49, 4325-4334. [CrossRef]

11. Daletou, M.K.; Geormezi, M.; Vogli, E.; Voyiatzis, G.A.; Neophytides, S.G. The interaction of $\mathrm{H}_{3} \mathrm{PO}_{4}$ and steam with PBI and TPS polymeric membranes. A TGA and Raman study. J. Mater. Chem. A 2014, 2, 1117-1127. [CrossRef]

12. Gourdoupi, N.; Triantafyllopoulos, N.; Deimede, V.; Pefkianakis, L.; Daletou, M.; Neophytides, S.; Kallitsis, J.K. Aromatic Polyether Copolymers and Polymer Blends and Fuel Cells Comprising the Same. U.S. Patent WO/2008/038162, 4 March 2008.

13. Daletou, M.K.; Geormezi, M.; Pefkianakis, E.K.; Morfopoulou, C.; Kallitsis, J.K. Fully aromatic copolyethers for high temperature polymer electrolyte membrane fuel cells. Fuel Cells 2010, 10, 35-44. [CrossRef]

14. Geormezi, M.; Deimede, V.; Gourdoupi, N.; Triantafyllopoulos, N.; Neophytides, S.; Kallitsis, J.K. Novel pyridine-based poly(ether sulfones) and their study in high temperature PEM fuel cells. Macromolecules 2008, 41, 9051-9056. [CrossRef]

15. Daletou, M.K.; Gourdoupi, N.; Kallitsis, J.K. Proton conducting membranes based on blends of PBI with aromatic polyethers containing pyridine units. J. Membr. Sci. 2005, 252, 115-122. [CrossRef]

16. Pefkianakis, E.K.; Deimede, V.; Daletou, M.K.; Gourdoupi, N.; Kallitsis, J.K. Novel polymer electrolyte membrane, based on pyridine containing poly(ether sulfone), for application in high-temperature fuel cells. Macromol. Rapid Commun. 2005, 26, 1724-1728. [CrossRef]

17. Appleby, A.J.; Baker, B.S. Oxygen reduction on platinum in trifluoromethane sulfonic acid. J. Electrochem. Soc. 1978, 125, 404-406. [CrossRef]

18. Zelenay, P.; Habib, M.A.; Bockris, J.O.M. Adsorption from solution on platinum: An in situ FTIR and radiotracer study. Langmuir 1986, 2, 393-405. [CrossRef]

19. Hsueh, K.-L.; Chang, H.H.; Chin, D.-T. Electrode kinetics of oxygen reduction on platinum in trifluoromethanesulphonic acid. Electrochim. Acta 1985, 30, 1137-1142. [CrossRef]

20. Kunz, H.R. Electrolyte migration in fuel cell modeling. Electrochem. Soc. Proc. 1999, 99-14, 191-207.

21. Mukerjee, S. Innovative non-PGM catalysts for high-temperature PEMFCs. In 2016 DOE Hydrogen and Fuel Cell Program Review; DOE Hydrogen and Fuel Cell Program: Washington, DC, USA, June 2016.

22. Li, Q.; Jensen, J.O.; Savinell, R.F.; Bjerrum, N.J. High temperature proton exchange membranes based on polybenzimidazoles for fuel cells. Prog. Polym. Sci. 2009, 34, 449-477. [CrossRef] 
23. Bose, S.; Kuila, T.; Nguyen, T.X.H.; Kim, N.H.; Lau, K.-T.; Lee, J.H. Polymer membranes for high temperature proton exchange membrane fuel cell: Recent advances and challenges. Prog. Polym. Sci. 2011, 36, 813-843. [CrossRef]

24. Asensio, J.A.; Sánchez, E.M.; Gómez-Romero, P. Proton-conducting membranes based on benzimidazole polymers for high-temperature PEM fuel cells. A chemical quest. Chem. Soc. Rev. 2010, 39, 3210-3239. [CrossRef] [PubMed]

25. Herring, A.M. Inorganic-polymer composite membranes for proton exchange membrane fuel cells. J. Macromol. Sci. C 2006, 46, 245-296. [CrossRef]

26. Alberti, G.; Casciola, M. Composite membranes for medium-temperature PEM fuel cells. Annu. Rev. Mater. Res. 2003, 33, 129-154. [CrossRef]

27. Costamagna, P.; Yang, C.; Bocarsly, A.B.; Srinivasan, S. Nafion ${ }^{\circledR} 115 /$ zirconium phosphate composite membranes for operation of PEMFCs above $100{ }^{\circ} \mathrm{C}$. Electrochim. Acta 2002, 47, 1023-1033. [CrossRef]

28. Atkins, J.R.; Sides, C.R.; Creager, S.E.; Harris, J.L.; Pennington, W.T.; Thomas, B.H.; DesMarteau, D.D. Effect of equivalent weight on water sorption, PTFE-like crystallinity, and ionic conductivity in bis[(perfluoroalkyl)sulfonyl] imide perfluorinated ionomers. J. New Mater. Electr. Syst. 2003, 6, 9-15.

29. Damay, F.; Klein, L.C. Transport properties of Nafion ${ }^{\mathrm{TM}}$ composite membranes for proton-exchange membranes fuel cells. Solid State Ion. 2003, 162-163, 261-267. [CrossRef]

30. Ruffmann, B.; Silva, H.; Schulte, B.; Nunes, S.P. Organic/inorganic composite membranes for application in DMFC. Solid State Ion. 2003, 162-163, 269-275. [CrossRef]

31. Aili, D.; Hansen, M.K.; Pan, C.; Li, Q.; Christensen, E.; Jensen, J.O.; Bjerrum, N.J. Phosphoric acid doped membranes based on Nafion ${ }^{\circledR}, \mathrm{PBI}$ and their blends-Membrane preparation, characterization and steam electrolysis testing. Int. J. Hydrog. Energy 2011, 36, 6985-6993. [CrossRef]

32. Si, Y.; Kunz, H.R.; Fenton, J.M. Nafion-teflon-Zr $\left(\mathrm{HPO}_{4}\right)_{2}$ composite membranes for high-temperature PEMFCs. J. Electrochem. Soc. 2004, 151, A623-A631. [CrossRef]

33. Kwak, S.H.; Yang, T.H.; Kim, C.S.; Yoon, K.H. Polymer composite membrane incorporated with a hygroscopic material for high-temperature PEMFC. Electrochim. Acta 2004, 50, 653-657. [CrossRef]

34. Kwak, S.H.; Yang, T.H.; Kim, C.S.; Yoon, K.H. Nafion/mordenite hybrid membrane for high-temperature operation of polymer electrolyte membrane fuel cell. Solid State Ion. 2003, 160, 309-315. [CrossRef]

35. Ramani, V.; Kunz, H.R.; Fenton, J.M. Investigation of Nafion ${ }^{\circledR} /$ HPA composite membranes for high temperature/low relative humidity PEMFC operation. J. Membr. Sci. 2004, 232, 31-44. [CrossRef]

36. Wasmus, S.; Valeriu, A.; Mateescu, G.D.; Tryk, D.A.; Savinell, R.F. Characterization of $\mathrm{H}_{3} \mathrm{PO}_{4}$-Equili-brated Nafion(r) 117 Membranes Using ${ }^{1} \mathrm{H}$ and ${ }^{31} \mathrm{P}$ NMR Spectroscopy. Solid State Ion. 1995, 80, 87-92. [CrossRef]

37. De Bruijn, F.A.; Dam, V.A.T.; Janssen, G.J.M. Review: Durability and degradation issues of PEM fuel cell components. Fuel Cells 2008, 8, 3-22. [CrossRef]

38. Teranishi, K.; Kawata, K.; Tsushima, S.; Hirai, S. Degradation mechanism of PEMFC under open circuit operation. Electrochem. Solid State 2006, 9, A475-A477. [CrossRef]

39. Curtin, D.E.; Lousenberg, R.D.; Henry, T.J.; Tangeman, P.C.; Tisack, M.E. Advanced materials for improved PEMFC performance and life. J. Power Sources 2004, 131, 41-48. [CrossRef]

40. Madden, T.; Weiss, D.; Cipollini, N.; Condit, D.; Gummalla, M.; Burlatsky, S.; Atrazhev, V. Degradation of polymer-electrolyte membranes in fuel cells: I. experimental. J. Electrochem. Soc. 2009, 156, B657-B662. [CrossRef]

41. Tang, H.; Peikang, H.S.; Jiang, S.P.; Wang, F.; Pan, M. A degradation study of Nafion proton exchange membrane of PEM fuel cells. J. Power Sources 2007, 170, 85-92. [CrossRef]

42. Rodgers, M.P.; Bonville, L.J.; Kunz, H.R.; Slattery, D.K.; Fenton, J.M. Fuel cell perfluorinated sulfonic acid membrane degradation correlating accelerated stress testing and lifetime. Chem. Rev. 2012, 112, 6075-6103. [CrossRef] [PubMed]

43. Hogarth, W.H.J.; Diniz da Costa, J.C.; Lu, G.Q. Solid acid membranes for high temperature $\left(>140^{\circ} \mathrm{C}\right)$ proton exchange membrane fuel cells. J. Power Sources 2005, 142, 223-237. [CrossRef]

44. Zaidi, S.M. J.; Mikhailenko, S.D.; Robertson, G.P.; Guiver, M.D.; Kaliaguine, S. Proton conducting composite membranes from polyether ether ketone and heteropolyacids for fuel cell applications. J. Membr. Sci. 2000, 173, 17-34. [CrossRef] 
45. Ma, C.; Zhang, L.; Mukerjee, S.; Ofer, D.; Nair, B. An investigation of proton conduction in select PEM's and reaction layer interfaces-designed for elevated temperature operation. J. Membr. Sci. 2003, 219, 123-136. [CrossRef]

46. Scott, K.; Taama, W.M.; Argyropoulos, P. Performance of the direct methanol fuel cell with radiation-grafted polymer membranes. J. Membr. Sci. 2000, 171, 119-130. [CrossRef]

47. Pohl, H.A.; Chartoff, R.P. Carriers and unpaired spins in some organic semiconductors. J. Polym. Sci. A 1964, 2, 2787-2806. [CrossRef]

48. Aharoni, S.M.; Signorelli, A.J. Electrical resistivity and ESCA studies on neutral poly(alkylbenzimidazoles), their salts, and complexes. J. Appl. Polym. Sci. 1979, 23, 2653-2660. [CrossRef]

49. Ma, Y.-L.; Wainright, J.S.; Litt, M.H.; Savinell, R.F. Conductivity of PBI membranes for high-temperature polymer electrolyte fuel cells. J. Electrochem. Soc. 2004, 151, A8-A16. [CrossRef]

50. He, R.; Li, Q.; Xiao, G.; Bjerrum, N.J. Proton conductivity of phosphoric acid doped polybenzimidazole and its composites with inorganic proton conductors. J. Membr. Sci. 2003, 226, 169-184. [CrossRef]

51. Gulledge, A.L.; Chen, X.; Benicewicz, B.C. Investigation of sequence isomer effects in AB-polybenzimidazole polymers. J. Polym. Sci. A Polym. Chem. 2014, 52, 619-628. [CrossRef]

52. Savinell, R.; Yeager, E.; Tryk, D.; Landau, U.; Wainright, J.; Weng, D.; Lux, K.; Litt, M.; Rogers, C. A polymer electrolyte for operation at temperatures up to $200{ }^{\circ} \mathrm{C}$. J. Electrochem. Soc. 1994, 141, L46-L48. [CrossRef]

53. Hazarika, M.; Jana, T. Proton exchange membrane developed from novel blends of polybenzimidazole and poly(vinyl-1,2,4-triazole). ACS Appl. Mater. Interfaces 2012, 4, 5256-5265. [CrossRef] [PubMed]

54. Samms, S.R.; Wasmus, S.; Savinell, R.F. Thermal stability of proton conducting acid doped polybenzimidazole in simulated fuel cell environments. J. Electrochem. Soc. 1996, 143, 1225-1232. [CrossRef]

55. Liu, G.; Zhang, H.; Hu, J.; Zhai, Y.; Xu, D.; Shao, Z.-G. Studies of performance degradation of a high temperature PEMFC based on $\mathrm{H}_{3} \mathrm{PO}_{4}$-doped PBI. J. Power Sources 2006, 162, 547-552. [CrossRef]

56. Zolfaghari, A.; Chayer, M. Jerkiewicz Energetics of the underpotential deposition of hydrogen on platinum electrodes I. Absence of coadsorbed species. J. Electrochem. Soc. 1997, 144, 3034-3041. [CrossRef]

57. Chandan, A.; Hattenberger, M.; El-kharouf, A.; Du, S.; Dhir, A.; Self, V.; Pollet, B.G.; Ingram, A.; Bujalski, W. High temperature (HT) polymer electrolyte membrane fuel cells (PEMFC)—A review. J. Power Sources 2013, 231, 264-278. [CrossRef]

58. Sheng, L.; Xu, H.; Guo, X.; Fang, J.; Fang, L.; Yin, J. Synthesis and properties of novel sulfonated polybenzimidazoles from disodium 4,6-bis(4-carboxyphenoxy)benzene-1,3-disulfonate. J Power Sources 2011, 196, 3039-3047. [CrossRef]

59. Mader, J.A.; Benicewicz, B.C. Synthesis and Properties of Segmented Block Copolymers of Functionalised Polybenzimidazoles for High-Temperature PEM Fuel Cells. Fuel Cells 2011, 11, 222-237. [CrossRef]

60. Mader, J.A.; Benicewicz, B.C. Sulfonated polybenzimidazoles for high temperature PEM fuel cells. Macromolecules 2010, 43, 6706-6715. [CrossRef]

61. Jensen, J.O.; Li, Q.; Pan, C.; Bjerrum, N.J.; Rudbeck, H.C.; Steenberg, T. Ongoing efforts addressing degradation of high temperature PEMFC. In Proceedings of the 18th World Hydrogen Energy Conference, Essen, Germany, 6-20 May 2010.

62. Mader, J.; Xiao, L.; Schmidt, T.J.; Benicewicz, B.C. Polybenzimidazole/acid complexes as high-temperature membranes. Adv. Polym. Sci. 2008, 216, 63-124.

63. Daletou, M.K.; Kallitsis, J.K.; Voyiatzis, G.; Neophytides, S.G. The interaction of water vapors with $\mathrm{H}_{3} \mathrm{PO}_{4}$ imbibed electrolyte based on PBI/polysulfone copolymer blends. J. Membr. Sci. 2009, 326, 76-83. [CrossRef]

64. Kalamaras, I.; Daletou, M.K.; Neophytides, S.G.; Kallitsis, J.K. Thermal crosslinking of aromatic polyethers bearing pyridine groups for use as high temperature polymer electrolytes. J. Membr. Sci. 2012, 415-416, 42-50. [CrossRef]

65. Papadimitriou, K.D.; Geormezi, M.; Neophytides, S.G.; Kallitsis, J. K Covalent cross-linking in phosphoric acid of pyridine based aromatic polyethers bearing side double bonds for use in high temperature polymer electrolyte membrane fuel cells. J. Membr. Sci. 2013, 433, 1-9. [CrossRef]

66. Cappadonia, M.; Niemzig, O.; Stimming, U. Preliminary study on the ionic conductivity of a polyphosphate composite. Solid State Ion. 1999, 125, 333-337. [CrossRef]

67. Heo, P.; Kajiyama, N.; Kobayashi, K.; Nagao, M.; Sano, M.; Hibino, T. Proton conduction in $\mathrm{Sn}_{0.95} \mathrm{Al}_{0.05} \mathrm{P}_{2} \mathrm{O}_{7} \mathrm{PBI}-\mathrm{PTFE}$ composite membrane. Electrochem. Solid-State Lett. 2008, 11, B91-B95. [CrossRef] 
68. Oh, S.-Y.; Yoshida, T.; Kawamura, G.; Muto, H.; Sakai, M.; Matsuda, A. Inorganic-organic composite electrolytes consisting of polybenzimidazole and Cs-substituted heteropoly acids and their application for medium temperature fuel cells. J. Mater. Chem. 2010, 20, 6359-6366. [CrossRef]

69. Liu, X.; Yu, E.H.; Scott, K. Preparation and evaluation of a highly stable palladium yttrium platinum core-shell-shell structure catalyst for oxygen reduction reactions. Appl. Catal. B Environ. 2015, 162, 593-601. [CrossRef]

70. Eda, G.; Chhowalla, M. Chemically derived graphene oxide: Towards large-area thin-film electronics and optoelectronics. Adv. Mater. 2010, 22, 2392-2415. [CrossRef] [PubMed]

71. Xu, C.; Liu, X.; Cheng, J.; Scott, K. A polybenzimidazole/ionic-liquid-graphite-oxide composite membrane for high temperature polymer electrolyte membrane fuel cells. J. Power Sources 2015, 274, 922-927. [CrossRef]

72. Staiti, P.; Minutoli, M.; Hocevar, S. Membranes based on phosphotungstic acid and polybenzimidazole for fuel cell application. J. Power Sources 2000, 90, 231-235. [CrossRef]

73. Staiti, P.; Minutoli, M. Influence of composition and acid treatment on proton conduction of composite polybenzimidazole membranes. J. Power Sources 2001, 94, 9-13. [CrossRef]

74. Staiti, P. Proton conductive membranes based on silicotungstic acid/silica and polybenzimidazole. Mater. Lett. 2001, 47, 241-246. [CrossRef]

75. Lobato, J.; Canizares, P.; Rodrigo, M.A.; Úbeda, D.; Pinar, F.J. Promising $\mathrm{TiOSO}_{4}$ composite polybenzimidazole-based membranes for high temperature PEMFCs. ChemSusChem 2011, 4, 1489-1497. [CrossRef] [PubMed]

76. Di, S.; Yan, L.; Han, S.; Yue, B.; Feng, Q.; Xie, L.; Chen, J.; Zhang, D.; Sun, C. Enhancing the high-temperature proton conductivity of phosphoric acid doped poly(2,5-benzimidazole) by preblending boron phosphate nanoparticles to the raw materials. J. Power Sources 2012, 211, 161-168. [CrossRef]

77. Suryani; Liu, Y.L. Preparation and properties of nanocomposite membranes of polybenzimidazole/ sulfonated silica nanoparticles for proton exchange membranes. J. Membr. Sci. 2009, 332, 121-128. [CrossRef]

78. Aili, D.; Allward, T.; Alfaro, S.M.; Hartmann-Thompson, C.; Steenberg, T.; Hjuler, H.A.; Li, Q.; Jensen, J.O.; Stark, E.J. Polybenzimidazole and sulfonated polyhedral oligosilsesquioxanecomposite membranes for high temperature polymer electrolytemembrane fuel cells. Electrochim. Acta 2014, 140, 182-190. [CrossRef]

79. Lobato, J.; Canizares, P.; Rodrigo, M.A.; Úbeda, D.; Pinar, F.J. A novel titanium PBI-based composite membrane for high temperature PEMFCs. J. Membr. Sci. 2011, 369, 105-111. [CrossRef]

80. Plackett, D.; Siu, A.; Li, Q.; Pan, C.; Jensen, J.O.; Nielsen, S.F.; Permyakova, A.A.; Bjerrum, N.J. High-temperature proton exchange membranes based on polybenzimidazole and clay composites for fuel cells. J. Membr. Sci. 2011, 383, 78-87. [CrossRef]

81. Kurdakova, V.; Quartarone, E.; Mustarelli, P.; Magistris, A.; Caponetti, E.; Saladino, M.L. PBI-based composite membranes for polymer fuel cells. J. Power Sources 2010, 195, 7765-7769. [CrossRef]

82. Ghosh, S.; Maity, S.; Jana, T. Polybenzimidazole/silica nanocomposites: Organic-inorganic hybrid membranes for PEM fuel cell. J. Mater. Chem. 2011, 21, 14897-14906. [CrossRef]

83. Kim, S.; Myles, T.D.; Kunz, H.R.; Kwak, D.; Wang, Y.; Maric, R. The effect of binder content on the performance of a high temperature polymer electrolyte membrane fuel cell produced with reactive spray deposition technology. Electrochim. Acta 2015, 177, 190-200. [CrossRef]

84. Myles, T.D.; Kim, S.; Maric, R.; Mustain, W.E. Application of a coated film catalyst layer model to a high temperature polymer electrolyte membrane fuel cell with low catalyst loading produced by reactive spray deposition technology. Catalysts 2015, 5, 1673-1691. [CrossRef]

85. Avgouropoulos, G.; Papavasiliou, J.; Daletou, M.K.; Kallitsis, J.K.; Ionnides, T.; Neophytides, S. Reforming methanol to electricity in a high temperature PEM fuel cell. Appl. Catal. B-Environ. 2009, 90, 628-632. [CrossRef]

86. Larminie, J.; Dicks, A. Fuel Cell Systems Explained, 2nd ed.; Wiley: West Sussex, UK, 2003; pp. $177-187$.

87. Mench, M. Fuel Cell Engines; John Wiley \& Sons: Hoboken, NJ, USA, 2008.

88. Breault, R.D. Stack materials and stack design. In Handbook of Fuel Cells-Fundamentals, Technology and Applications; Vielstich, W., Lamm, A., Gasteiger, H.A., Eds.; Wiley: New York, NY, USA, 2003; Volume 4, pp. 797-810.

89. Breault, R.D. Method for Reducing Electrolyte Loss from an Electrochemical Cell. U.S. Patent 4,414,291, 8 November 1983. 
90. Yu, S.; Xiao, L.; Benicewicz, B.C. Durability studies of PBI-based high temperature PEMFCs. Fuel Cells 2008, 8, 165-174. [CrossRef]

91. Wannek, C.; Kohnen, B.; Oetjen, H.-F.; Lippert, H.; Mergel, J. Durability of ABPBI-based MEAs for high temperature PEMFCs at different operating conditions. Fuel Cells 2008, 8, 87-95. [CrossRef]

92. Lobato, J.; Canizares, P.; Rodrigo, M.A.; Ubeda, D.; Pinar, F.J. Enhancement of the fuel cell performance of a high temperature proton exchange membrane fuel cell running with titanium composite polybenzimidazole-based membranes. J. Power Sources 2011, 196, 8265-8271. [CrossRef]

93. Pinar, F.J.; Canizares, P.; Rodrigo, M.A.; Ubeda, D.; Lobato, J. Titanium composite PBI-based membranes for high temperature polymer electrolyte membrane fuel cells. Effect on titanium dioxide amount. RSC Adv. 2012, 2, 1547-1556. [CrossRef]

94. Pinar, F.J.; Canizares, P.; Rodrigo, M.A.; Ubeda, D.; Lobato, J. Long-term testing of a high-temperature proton exchange membrane fuel cell short stack operated with improved polybenzimidazole-based composite membranes. J. Power Sources 2015, 274, 177-185. [CrossRef]

95. Wang, Y.-J.; Zhao, N.; Fang, B.; Li, H.; Bi, X.T.; Wang, H. Carbon-supported Pt-based alloy electrocatalysts for the oxygen reduction reaction in polymer electrolyte membrane fuel cells: Particle size, shape, and composition manipulation and their impact to activity. Chem. Rev. 2015, 115, 3433-3467. [CrossRef] [PubMed]

96. Debe, M.K. Electrocatalyst approaches and challenges for automotive fuel cells. Nature 2012, 486, 43-51. [CrossRef] [PubMed]

97. Chen, Z.; Higgins, D.; Yu, A.; Zhang, L.; Zhang, J. A review on non-precious metal electrocatalysts for PEM fuel cells. Energy Environ. Sci. 2011, 4, 3167-3192. [CrossRef]

98. Shao, Y.; Cheng, Y.; Duan, W.; Wang, W.; Lin, Y.; Wang, Y.; Liu, J. Nanostructured electrocatalysts for PEM fuel cells and redox flow batteries: A selected review. ACS Catal. 2015, 5, 7288-7298. [CrossRef]

99. Zhang, J. Recent advances in cathode electrocatalysts for PEM fuel cells. Front. Energy 2011, 5, 137-148. [CrossRef]

100. Luczak, F.J.; Landsman, D.A. Ternary Fuel Cell Catalysts Containing Platinum, Cobalt and Chromium. U.S. Patent 4,447,506, 8 May 1984.

101. Luczak, F.J.; Douglas, A. Ordered Ternary Fuel Cell Catalysts Containing Platinum and Cobalt. U.S. Patent 4,711,829, 8 December 1987.

102. Luczak, F.J.; Landsman, D.A. Ordered Ternary Fuel Cell Catalysts Containing Platinum and Cobalt and Method for Making the Catalysts. U.S. Patent 4,677,092, 30 June 1987.

103. Landsman, D.A.; Luczak, F.J. Noble Metal-Chromium Alloy Catalysts and Electrochemical Cell. U.S. Patent 4,316,944, 23 February 1982.

104. Beard, B.C.; Ross, P.N. The structure and activity of Pt-Co alloys as oxygen reduction electrocatalysts. J. Electrochem. Soc. 1990, 137, 3368-3374. [CrossRef]

105. Glass, J.T.; Cahen, G.L.; Stoner, G.E.; Taylor, E.J. The effect of metallurgical variables on the electrocatalytic properties of PtCr alloys. J. Electrochem. Soc. 1987, 134, 58-65. [CrossRef]

106. Paulus, U.A.; Wokaun, A.; Scherer, G.G.; Schmidt, T.J.; Stamenkovic, V.; Radmilovic, V.; Markovic, N.M.; Ross, P.N. Oxygen reduction on carbon-supported Pt-Ni and Pt-Co alloy catalysts. J. Phys. Chem. B 2002, 106, 4181-4191. [CrossRef]

107. Min, M.-K.; Cho, J.; Cho, K.; Kim, H. Particle size and alloying effects of Pt-based alloy catalysts for fuel cell applications. Electrochim. Acta 2000, 45, 4211-4217. [CrossRef]

108. Aricò, A.S.; Stassi, A.; Modica, E.; Ornelas, R.; Gatto, I.; Passalacqua, E.; Antonucci, V. Performance and degradation of high temperature polymer electrolyte fuel cell catalysts. J. Power Sources 2008, 178, 525-536. [CrossRef]

109. Parrondo, J.; Mijangos, F.; Rambabu, B. Platinum/tin oxide/carbon cathode catalyst for high temperature PEM fuel cell. J. Power Sources 2010, 195, 3977-3983. [CrossRef]

110. Rao, C.V.; Parrondo, J.; Ghatty, S.L.; Rambabu, B. High temperature polymer electrolyte membrane fuel cell performance of $\mathrm{Pt}_{\mathrm{x}} \mathrm{Co}_{\mathrm{y}} / \mathrm{C}$ cathodes. J. Power Sources 2010, 195, 3425-3430. [CrossRef]

111. Jalan, V.M.; Taylor, E.J. Importance of interatomic spacing in catalytic reduction of oxygen in phosphoric acid. J. Electrochem. Soc. 1983, 130, 2299-2302. [CrossRef]

112. Kim, K.T.; Kim, Y.G.; Chung, J.S. Effect of surface roughening on the catalytic activity of Pt-Cr electrocatalysts for the oxygen reduction in phosphoric acid fuel cell. J. Electrochem. Soc. 1995, 142, 1531-1538. [CrossRef] 
113. Daube, K.A.; Paffett, M.T.; Gottesfeld, S.; Campbell, C.T. Combined electrochemical/surface science investigations of Pt/Cr alloy electrodes. J. Vac. Sci. Technol. A 1986, 4, 1617-1620. [CrossRef]

114. Paffett, M.T.; Beery, J.G.; Gottesfeld, S. Oxygen reduction at $\mathrm{Pt}_{0.65} \mathrm{Cr}_{0.35}, \mathrm{Pt}_{0.2} \mathrm{Cr}_{0.8}$ and roughened platinum. J. Electrochem Soc. 1988, 135, 1431-1436. [CrossRef]

115. Zagudaeva, N.M.; Tarasevich, M.R. Electrochemical characteristics of platinum-based binary catalysts for middle-temperature hydrogen-air fuel cells with phosphoric acid electrolyte. Russ. J. Electrochem. 2010, 46, 530-536. [CrossRef]

116. Schenk, A.; Grimmer, C.; Perchthaler, M.; Weinberger, S.; Pichler, B.; Heinzl, C.; Scheu, C.; Mautner, F.-A.; Bitschnau, B.; Hacker, V. Platinum-cobalt catalysts for the oxygen reduction reaction in high temperature proton exchange membrane fuel cells-Long term behavior under ex-situ and in-situ conditions. J. Power Sources 2014, 266, 313-322. [CrossRef]

117. Zamora, H.; Canizares, P.; Rodrigo, M.A.; Lobato, J. Improving of micro porous layer based on advanced carbon materials for high temperature proton exchange membrane fuel cell electrodes. Fuel Cells 2015, 15, 375-383. [CrossRef]

118. Zamora, H.; Plaza, J.; Canizares, P.; Lobato, J.; Rodrigo, M.A. Improved electrodes for high temperature proton exchange membrane fuel cells using carbon nanospheres. ChemSusChem 2016, 9, 1187-1193. [CrossRef] [PubMed]

119. Lobato, J.; Zamora, H.; Canizares, P.; Plaza, J.; Rodrigo, M.A. Microporous layer based on SiC for high temperature proton exchange membrane fuel cells. J. Power Sources 2015, 288, 288-295. [CrossRef]

120. Lobato, J.; Zamora, H.; Plaza, J.; Canizares, P.; Rodrigo, M.A. Enhancement of high temperature PEMFC stability using catalysts based on Pt supported on SiC based materials. Appl. Catal. B Environ. 2016, 198, 516-524. [CrossRef]

121. Lobato, J.; Zamora, H.; Plaza, J.; Rodrigo, M.A. Composite titanium silicon carbide as a promising catalyst support for high-temperature proton-exchange membrane fuel cell electrodes. Chem CatChem 2016, 8, 848-854. [CrossRef]

122. Razaq, M.; Yeager, E.; DesMarteau, D.D.; Singh, S. Perfluorosulfonimide as an additive in phosphoric acid fuel cell. J. Electrochem. Soc. 1989, 136, 385-390. [CrossRef]

123. Gang, X.; Hjuler, H.A.; Olsen, C.; Berg, R.W.; Bjerrum, N.J. Electrolyte additives for phosphoric acid fuel cells. J. Electrochem. Soc. 1993, 140, 896-902. [CrossRef]

124. Qingfeng, L.; Gang, X.; Hjuler, H.A.; Berg, R.W.; Bjerrum, N.J. Limiting current of oxygen reduction on gas-diffusion electrodes for phosphoric acid fuel cells. J. Electrochem. Soc. 1994, 141, 3114-3119. [CrossRef]

125. Qingfeng, L.; Gang, X.; Hjuler, H.A.; Berg, R.W.; Bjerrum, N.J. Oxygen reduction on gas diffusion electrodes for phosphoric acid fuel cells by a potential decay method. J. Electrochem Soc. 1995, 142, 3250-3256. [CrossRef]

126. Qingfeng, L.; Hjuler, H.A.; Bjerrum, N.J. Oxygen reduction on carbon supported platinum catalysts in high temperature polymer electrolytes. Electrochim. Acta 2000, 45, 4219-4226. [CrossRef]

127. Hong, S.-G.; Kwon, K.; Lee, M.-J.; Yoo, D.Y. Performance enhancement of phosphoric acid-based proton exchange membrane fuel cells by using ammonium trifluoromethanesulfonate. Electrochem. Commun. 2009, 11, 1124-1126. [CrossRef]

128. Mamlouk, M.; Scott, K. The effect of electrode parameters on performance of a phosphoric acid-doped PBI membrane fuel cell. Int. J. Hydrog. Energy 2010, 35, 784-793. [CrossRef]

129. Mamlouk, M.; Scott, K. Phosphoric acid-doped electrodes for a PBI polymer membrane fuel cell. Int. J. Energy Res. 2011, 35, 507-519. [CrossRef]

130. Adams, A.A.; Foley, R.T.; Barger, H.J., Jr. The electroreduction of air in trifluoromethanesulfonic acid monohydrate. J. Electrochem. Soc. 1977, 124, 1228-1230. [CrossRef]

131. Enayetullah, M.A.; Devilbiss, T.D.; Bockris, J.O.M. Activation parameters for oxygen reduction kinetics in trifluoromethane sulfonic acid systems. J. Electrochem. Soc. 1989, 136, 3369-3376. [CrossRef]

132. George, M. Aqueous Trifluoromethanesulfonic Acid Fuel Cells; Technical Report, U.S. Army Mobility Equipment Research and Development Command, Contract No. DAAK70-78-C-0103; Ft. Belvoir Defense Technical Information Center: Fort Belvoir, VA, USA, 1979.

133. Baker, B. Electrolyte for Hydrocarbon Air Fuel Cells; Final Technical Report, U.S. Army Mobility Equipment Research and Development Command, Contract No. DAAK02-73-C-0084; Ft. Belvoir Defense Technical Information Center: Fort Belvoir, VA, USA, 1975. 
134. Liu, Z.; Wainright, J.S.; Litt, M.H.; Savinell, R.F. Study of the oxygen reduction reaction (ORR) at Pt interfaced with phosphoric acid doped polybenzimidazole at elevated temperature and low relative humidity. Electrochim. Acta 2006, 51, 3914-3923. [CrossRef]

135. Kwon, K.; Lee, M.-J. Effect of calixpyrrole on electrochemical properties of Pt electrocatalyst in phosphoric acid electrolyte. Electrochim. Acta 2008, 54, 513-517. [CrossRef]

136. Striebel, K.A.; Andricacos, P.C.; Cairns, E.J.; Ross, P.N.; McLarnon, F.R. Oxygen reduction in tetrafluoroethane-1,2-disulfonic acid. J. Electrochem. Soc. 1985, 132, 2381-2384. [CrossRef]

137. Saffarian, H.; Ross, P.; Behr, F.; Gard, G. Electrochemical properties of perfluoroalkane disulfonic $\left[\mathrm{HSO}_{3}(\mathrm{CF} 2)_{\mathrm{n}} \mathrm{SO}_{3} \mathrm{H}\right]$ acids relevant to fuel cell technology. J. Electrochem. Soc. 1992, 139, 2391-2397. [CrossRef]

138. Kanamura, K.; Tanaka, A.; Gervasio, D.; Kennedy, V.; Adzic, R.; Yeager, E.B.; Burton, D.; Guneratne, R. Perfluoro-ethylene-1,2-bis-phosphonic acid fuel cell electrolyte. J. Electrochem. Soc. 1996, 143, 2765-2770. [CrossRef]

139. Heider, E.; Ignatiev, N.; Jörissen, L.; Wenda, A.; Zeis, R. Fluoroalkyl phosphoric acid derivatives-Model compounds to study the adsorption of electrolyte species on polycrystalline platinum. Electrochem. Commun. 2014, 48, 24-27. [CrossRef]

140. Ignat'ev, N.V.; Bejan, D.; Willner, H. Perfluoroalkylphosphorus acids synthesis, properties and applications in catalysis. Oggi/Chem. Today 2011, 29, 32-34.

141. Herath, M.B.; Creager, S.E.; Kitaygorodskiy, A.; DesMarteau, D.D. Perfluoroalkyl phosphonic and phosphinic acids as proton conductors for anhydrous proton-exchange membranes. ChemPhysChem 2010, 11, 2871-2878. [CrossRef] [PubMed]

142. Herath, M.B.; Creager, S.E.; Kitaygorodskiy, A.; DesMarteau, D.D. Effect of perfluoroalkyl chain length on proton conduction in fluoroalkylated phosphonic, phosphinic, and sulfonic acids. J. Phys. Chem. B 2010, 114, 14972-14976. [CrossRef] [PubMed]

143. Heider, E.; Jusys, Z.; Behm, R.J.; Jörissen, L.; Zeis, R. Perfluoroalkyl-phosphonic acid adsorption on polycrystalline platinum and its influence on the oxygen reduction reaction. J. Phys. Chem. C 2015, 119, 18859-18869. [CrossRef]

144. Mack, F.; Galbiati, S.; Gogel, V.; Jörissen, L.; Zeis, R. Evaluation of electrolyte additives for high-temperature polymer electrolyte fuel cells. ChemElectroChem 2016, 3, 770-773. [CrossRef]

145. Lee, K.-S.; Yoo, S.J.; Ahn, D.; Kim, S.-K.; Hwang, S.J.; Sung, Y.-E.; Kim, H.-J.; Cho, E.; Henkensmeier, D.; Lim, T.-H.; et al. Phosphate adsorption and its effect on oxygen reduction reaction for $\mathrm{Pt}_{x} \mathrm{Co}_{y}$ alloy and $\mathrm{Au}_{\text {core }}-\mathrm{Pt}_{\text {shell }}$ electrocatalysts. Electrochim. Acta 2011, 56, 8802-8810. [CrossRef]

146. He, Q.; Shyam, B.; Nishijima, M.; Ramaker, D.; Mukerjee, S. Mitigating phosphate anion poisoning of cathodic Pt/C catalysts in phosphoric acid fuel cells. J. Phys. Chem. C 2013, 117, 4877-4887. [CrossRef]

147. Tanaka, A.; Adzic, R.; Nikolic, B. Oxygen reduction on single crystal platinum electrodes in phosphoric acid solutions. J. Serb. Chem. Soc. 1999, 64, 695-705.

(c) 2017 by the authors; licensee MDPI, Basel, Switzerland. This article is an open access article distributed under the terms and conditions of the Creative Commons Attribution (CC-BY) license (http:/ / creativecommons.org/licenses/by/4.0/). 